\title{
Global anthropogenic methane emissions 2005-2030: technical mitigation potentials and costs
}

\author{
L. Höglund-Isaksson \\ International Institute for Applied Systems Analysis, Laxenburg, Austria \\ Correspondence to: L. Höglund-Isaksson (hoglund@iiasa.ac.at) \\ Received: 10 February 2012 - Published in Atmos. Chem. Phys. Discuss.: 3 May 2012 \\ Revised: 4 September 2012 - Accepted: 5 September 201 - Published: 4 October 2012
}

\begin{abstract}
This paper presents estimates of current and future global anthropogenic methane emissions, their technical mitigation potential and associated costs for the period 2005 to 2030. The analysis uses the GAINS model framework to estimate emissions, mitigation potentials and costs for all major sources of anthropogenic methane for 83 countries/regions, which are aggregated to produce global estimates. Global emissions are estimated at $323 \mathrm{Mt}$ methane in 2005, with an expected increase to $414 \mathrm{Mt}$ methane in 2030 . The technical mitigation potential is estimated at $195 \mathrm{Mt}$ methane in 2030 , whereof about 80 percent is found attainable at a marginal cost less than 20 Euro $^{-1} \mathrm{CO}_{2} \mathrm{eq}$ when using a social planner cost perspective. With a private investor cost perspective, the corresponding fraction is only 30 percent. Major uncertainty sources in emission estimates are identified and discussed.
\end{abstract}

\section{Introduction}

Methane $\left(\mathrm{CH}_{4}\right)$ is a greenhouse gas currently contributing to about 15 percent of global anthropogenic greenhouse gases emitted every year when assuming a greenhouse warming potential (GWP) of 25 times carbon dioxide $\left(\mathrm{CO}_{2}\right)$ over $100 \mathrm{yr}$ (IPCC, 2007). As $\mathrm{CH}_{4}$ has a relatively short perturbation lifetime of $12 \mathrm{yr}$ in the atmosphere, the GWP over $20 \mathrm{yr}$ is considerably higher at 72 times that of $\mathrm{CO}_{2}$ (IPCC, 2007). With this shorter time horizon, $\mathrm{CH}_{4}$ emissions account for about 35 percent of global anthropogenic greenhouse gas emissions. Hence $\mathrm{CH}_{4}$ is an important source of anthropogenic greenhouse gas emissions, and its mitigation is especially important for controlling climate change in the near term (Shindell et al., 2012).
This work identifies important sources of global $\mathrm{CH}_{4}$ emissions, the possibilities for reducing these emissions, and associated mitigation costs. It also points out major sources of uncertainty and highlights critical gaps in knowledge. The presented work is an update and extension of previous work on $\mathrm{CH}_{4}$ using the GAINS model (Höglund-Isaksson and Mechler, 2005; Cofala et al., 2007; UNEP, 2011), see Sect. 3.2 for a comparison.

Global anthropogenic $\mathrm{CH}_{4}$ emissions with technical mitigation potentials and costs are estimated for the period 2005 to 2030. Forty source sectors for $\mathrm{CH}_{4}$ are identified and region-specific estimates for 83 world regions are produced using the Greenhouse gas and Air pollution Interactions and Synergies (GAINS) model (http://gains.iiasa.ac.at/) framework. All major anthropogenic sources of $\mathrm{CH}_{4}$ are covered, i.e. livestock, rice cultivation, biodegradable solid waste, wastewater, coal mining, oil and gas production, gas transmission pipelines, gas distribution networks and combustion of fuel used for energy consumption and from open burning of agricultural waste residuals. Other types of open burning of biomass for non-energy purposes, e.g. pre-scribed savannah burning or human-induced forest fires, are excluded from the analysis due to lack of systematic information.

Section 2 presents the methodology applied to estimations of emissions and mitigation costs. Results are summarized in Sect. 3 with comparison of results to other studies. A discussion of uncertainty issues is included in Sect. 4, while Sect. 5 concludes the analysis. For more detailed descriptions on emission estimations, mitigation potentials and costs, the reader is referred to the Supplement. 


\section{Methodology}

\section{1 $\mathrm{CH}_{4}$ emission estimations in GAINS}

\subsubsection{General emission estimation methodology}

Estimation of $\mathrm{CH}_{4}$ emissions in GAINS follows the methodology recommended by IPCC (2006) as closely as available data allows. With the ambition to produce as consistent estimates across regions as possible, an extensive compilation of country-specific information on parameters with significant effects on emissions was undertaken. This makes it possible to present estimates for several sources that go deeper than what is possible with IPCC Tier 1 methods. It also provides an opportunity to improve the understanding of the consistency and uncertainty in emissions reported by countries to UNFCCC and other inventories. For a detailed description of the estimation methodology applied and the reference sources used for each sector, please consult the Supplement.

In the general GAINS methodology (Amann et al., 2011), emissions from source $s$ in region $i$ and year $t$ are calculated as the activity data $A_{i t s}$ times an emission factor ef $_{i s m}$. If emissions are controlled through implementation of technology $m$, the fraction of the activity controlled is specified by $\operatorname{Appl}_{i t s m}$, i.e.

$E_{i t s}=\sum_{m}\left[A_{i t s} \cdot \mathrm{ef}_{i s m} \cdot \mathrm{Appl}_{i t s m}\right]$,

where

$\mathrm{ef}_{i s m}=\mathrm{ef}_{i s}^{\mathrm{NOC}} \cdot\left(1-\operatorname{remeff}_{s m}\right)$ and $\sum_{m} \mathrm{Appl}_{i t s m}=1$,

and where $A_{i t s}$ is the activity (e.g. number of animals, amounts of fuel or waste), $\mathrm{ef}_{i s m}$ is the emission factor for the fraction of the activity subject to control by technology $m$, Applitsm is the application rate of technology $m$ to activity $s, \mathrm{ef}_{i s}^{\mathrm{NOC}}$ is the no control emission factor for activity $s$, and remeff ${ }_{s m}$ is the removal efficiency of technology $m$ when applied to activity $s$.

Hence, the activity data specified for a particular sector, country and year is allocated to different technology specifications using application rates. The sum of the application rates of all technologies specified for a certain sector, including the application rate for no control, will always be unity. When there are several mitigation technology options available in the same sector, technologies are added sequentially. The most preferred technology (usually the cheapest one) is first adopted to its maximum, thereby removing a fraction of emissions corresponding to its removal efficiency. Then follows adoption of the second preferred technology on the remaining emissions, again removing emissions in correspondence with the removal efficiency of the technology, and so on for each additional technology adopted in the sector.

\subsubsection{Activity data}

In GAINS, activity drivers for emission projections enter calculations externally and are taken from international sources as presented in Table 1. For the analysis on global $\mathrm{CH}_{4}$, energy and macroeconomic projections are taken from the IEA World Energy Outlook Reference scenario 2009 (IEAWEO, 2009). Agricultural activities are taken from FAOSTAT (2010) and EUROSTAT (2009) for historical years with projections following FAO (2003) for all world regions except for Europe, where a more recent scenario from the CAPRI model (2009) has been used. The main difference between the FAO and CAPRI projections for Europe, is that FAO projects a slight decline in pig numbers by 4 percent between 2000 and 2030, while the more recent CAPRI scenario projects an increase by 18 percent over the same period. Expected declines in cattle numbers in Europe are comparable in the two scenarios. Figure 1 shows the future development of major external drivers for $\mathrm{CH}_{4}$ emissions on a global scale between $2005(=100)$ and 2030.

\subsubsection{Emission factors}

Whenever data availability allows, emission factors have been derived using country-specific information for important parameters. It is however often difficult to bridge all gaps in the country-specific information needed to produce full IPCC Tier 2 emission estimates. These gaps have then been filled with default assumptions taken from IPCC (2006) or other sources. Table 2 presents the basic methodology applied to different emission sources and the country specific and non-country specific information used to produce emission estimates. For a more comprehensive description of the calculation methods applied, the references used and the identified sources of uncertainty in estimations, please refer to the Supplement.

The resulting GAINS emission estimates for 2005 were compared with the emission inventory for countries reporting to UNFCCC (2010) in the Common Reporting Formats (CRFs) and the National Inventory Reports (NIRs). Discrepancies were carefully investigated and adjustments made when appropriate, i.e. to the extent that the consistency in methodology across countries is preserved (HöglundIsaksson et al., 2009).

\section{2 $\mathrm{CH}_{4}$ mitigation and cost estimation in GAINS}

\subsubsection{Technically feasible $\mathrm{CH}_{4}$ mitigation options}

The mitigation potential assessed in this analysis refers to reductions in emissions through application of technologies that are currently commercially available and already implemented at least to a limited extent. Hence, more speculative mitigation options, e.g. large-scale vaccination of livestock or application of propionate precursors to combat enteric fermentation emissions, are not included (Ecofys, 2009; 
Table 1. GAINS $\mathrm{CH}_{4}$ emission sources, activity data and drivers.

\begin{tabular}{|c|c|c|}
\hline Emission source & Historical activity data & Projection driver \\
\hline $\begin{array}{l}\text { Oil and natural gas production - venting } \\
\text { of associated gas }\end{array}$ & $\begin{array}{l}\text { Oil and natural gas production } \\
\text { (IEA-WEO, 2009) }\end{array}$ & $\begin{array}{l}\text { Future oil and natural gas production } \\
\text { (IEA-WEO, 2009) }\end{array}$ \\
\hline $\begin{array}{l}\text { Oil and natural gas production - } \\
\text { unintended leakage }\end{array}$ & $\begin{array}{l}\text { Oil and natural gas production } \\
\text { (IEA-WEO, 2009) }\end{array}$ & $\begin{array}{l}\text { Future oil and natural gas production } \\
\text { (IEA-WEO, 2009) }\end{array}$ \\
\hline Combustion - Flaring of associated gas & $\begin{array}{l}\text { Oil and natural gas production } \\
\text { (IEA-WEO, 2009) }\end{array}$ & $\begin{array}{l}\text { Future oil and natural gas production } \\
\text { (IEA-WEO, 2009) }\end{array}$ \\
\hline Long-distance natural gas transmission & $\begin{array}{l}\text { Volume transported and length of on- } \\
\text { shore pipelines (UNFCCC, 2010; IEA- } \\
\text { WEO, 2009; IEA, 2010; Wuppertal In- } \\
\text { stutite, 2005; CIA World Fact book, } \\
\text { 2010) }\end{array}$ & $\begin{array}{l}\text { Future gas consumption } \\
\text { (IEA-WEO, 2009) }\end{array}$ \\
\hline Gas distribution networks & $\begin{array}{l}\text { Gas consumption by sector (IEA-WEO, } \\
\text { 2009) }\end{array}$ & $\begin{array}{l}\text { Future gas consumption } \\
\text { (IEA-WEO, 2009) }\end{array}$ \\
\hline Coal mining & Coal production (IEA-WEO, 2009) & $\begin{array}{l}\text { Future coal production } \\
\text { (IEA-WEO, 2009) }\end{array}$ \\
\hline Combustion - fossil and bio fuels & $\begin{array}{l}\text { Fuel consumption by sector } \\
\text { (IEA-WEO, 2009) }\end{array}$ & $\begin{array}{l}\text { Future fuel consumption } \\
\text { (IEA-WEO, 2009) }\end{array}$ \\
\hline Livestock & $\begin{array}{l}\text { Livestock numbers by animal type } \\
\text { (FAOSTAT, 2010; EUROSTAT, 2009; } \\
\text { UNFCCC, 2010) }\end{array}$ & $\begin{array}{l}\text { Growth in livestock numbers from FAO } \\
\text { (2003), CAPRI model (2009) }\end{array}$ \\
\hline Rice cultivation & $\begin{array}{l}\text { Land area for rice cultivation } \\
\text { (FAOSTAT, 2010) }\end{array}$ & $\begin{array}{l}\text { Growth in land area for rice cultivation } \\
\text { (FAO, 2003) }\end{array}$ \\
\hline $\begin{array}{l}\text { Combustion - agricultural waste } \\
\text { burning }\end{array}$ & $\begin{array}{l}\text { Amount of agricultural waste burned } \\
\text { (UNFCCC, 2010; Niemi, 2006) }\end{array}$ & Niemi (2006) \\
\hline Biodegradable municipal solid waste & $\begin{array}{l}\text { MSW generation per capita (EURO- } \\
\text { STAT, 2009; Eawag, 2008; IPCC, 1997) }\end{array}$ & $\begin{array}{l}\text { Data from EUROSTAT (2005) used to } \\
\text { estimate elasticity for waste generation } \\
\text { to growth in GDP per capita and urban- } \\
\text { ization rate from IEA-WEO (2009) }\end{array}$ \\
\hline Biodegradable industrial solid waste & $\begin{array}{l}\text { Amounts of waste generated derived } \\
\text { from country report to EUROSTAT } \\
(2005) \text { and related to sub-industry value } \\
\text { added. }\end{array}$ & $\begin{array}{l}\text { Data from EUROSTAT (2005) used to } \\
\text { estimate elasticity for waste generation } \\
\text { to growth in industry value added from } \\
\text { IEA-WEO (2009) }\end{array}$ \\
\hline Domestic wastewater & $\begin{array}{l}\text { Population connected to centralized } \\
\text { wastewater collection (UNFCCC, } \\
\text { 2010; FAO, 2009; UN, 2009, 2010) }\end{array}$ & $\begin{array}{l}\text { Population growth from } \\
\text { IEA-WEO (2009) }\end{array}$ \\
\hline Industrial wastewater & $\begin{array}{l}\text { Relevant industry production } \\
\text { (FAOSTAT, 2011; USDA, 2011; EC, } \\
\text { 2003) }\end{array}$ & $\begin{array}{l}\text { Growth in industry value added from } \\
\text { IEA-WEO (2009) }\end{array}$ \\
\hline
\end{tabular}

Newbold et al., 2005; Wright et al., 2004). Non-technical mitigation options that involve changes in human behaviour and preferences, e.g. changes in human diets towards consumption of less meat and milk products, are also excluded from the analysis. It should be noted that the technical mitigation potential is different from the politically feasible mitigation potential as the latter also takes into account costs and political barriers for implementation. Because technologies included in the analysis are commercially available and already fairly well developed, significant improvements are not expected over the coming two decades. Hence, no technological development is assumed and mitigation effectiveness and costs per activity unit remain constant over the analyzed period. This assumption together with including only 
Table 2. Methodology for $\mathrm{CH}_{4}$ emission estimations in the GAINS model (for references, see Supplement).

\begin{tabular}{|c|c|c|c|}
\hline Emission source & Emission calculation method & Country-specific factors used for deriving emission factors & Non-country specific factors used for deriving emission factors \\
\hline \multirow{6}{*}{$\begin{array}{l}\text { Oil and natural gas production } \\
\text { - venting of associated gas }\end{array}$} & \multirow{6}{*}{ IPCC Tier 2 (2006, Vol. 2, 4.43-4.35) } & Types of hydrocarbons produced & \multirow{2}{*}{$\begin{array}{l}\text { Vented associated gas as fraction of gas vented or flared by type of } \\
\text { hydrocarbon. }\end{array}$} \\
\hline & & Fraction offshore production & \\
\hline & & $\begin{array}{l}\text { Associated gas as fraction of hydrocarbons produced (by energy } \\
\text { content) }\end{array}$ & \multirow{4}{*}{ Methane content of associated gas is assumed 86 percent. } \\
\hline & & Fraction of associated gas reinjected/recovered & \\
\hline & & Fraction of associated gas flared or vented & \\
\hline & & Satellite images of flares & \\
\hline $\begin{array}{l}\text { Oil and natural gas production } \\
\text { - unintended leakage }\end{array}$ & IPCC Tier 1 (2006, Vol. 2, p. 4.41) & No country-specific information used & IPCC Tier 1 default emission factors. \\
\hline $\begin{array}{l}\text { Combustion - Flaring of } \\
\text { associated gas }\end{array}$ & IPCC Tier 2 (2006, Vol. 2, 4.43-4.35) & $\begin{array}{l}\text { Country-specific volumes of flared associated gas consistent } \\
\text { with derived vented emissions and verified against satellite im- } \\
\text { ages of flares. }\end{array}$ & Combustion efficiency of flares assumed to 98 percent. \\
\hline \multirow{2}{*}{$\begin{array}{l}\text { Long-distance natural gas } \\
\text { transmission }\end{array}$} & \multirow{2}{*}{ Variant of IPCC Tier 2 (2006, Vol. 2, p. 4.43) } & Length of on-shore pipelines & \multirow{2}{*}{$\begin{array}{l}\text { Emission factors in } \mathrm{kg} \mathrm{CH}_{4} \mathrm{bcm}^{-1} \mathrm{~km}^{-1} \text { derived for nine reference } \\
\text { countries, which were applied to comparable world regions. }\end{array}$} \\
\hline & & Volume of gas transported & \\
\hline \multirow{2}{*}{ Gas distribution networks } & \multirow{2}{*}{ Country reports to UNFCCC (2010) } & \multirow{2}{*}{ Country-specific leakage rates for Annex-1 countries. } & $\begin{array}{l}\text { Split of total losses by residential and non-residential users based on } \\
\text { measurement results for the UK. }\end{array}$ \\
\hline & & & $\begin{array}{l}\text { UK leakage rates applied to Non-Annex-1 countries, except Former So- } \\
\text { viet Union where Russian leakage rates applied. }\end{array}$ \\
\hline \multirow{5}{*}{ Coal mining } & \multirow{5}{*}{$\begin{array}{l}\text { IPCC Tier } 2(2006, \text { Vol. } 2,4.10-4.20) \text { for pre- } \\
\text { mining and mining emissions and IPCC Tier } 1 \\
\text { for post-mining emissions. }\end{array}$} & $\begin{array}{l}\text { Methane emissions (mining and post-mining before recovery) } \\
\text { per ton coal produced. }\end{array}$ & IPCC Tier 1 default emission factors for post-mining emissions. \\
\hline & & Fractions brown and hard coal produced. & \multirow{4}{*}{$\begin{array}{l}\text { For derivation of emission factors, missing country specific information } \\
\text { was replaced by default assumptions. }\end{array}$} \\
\hline & & $\begin{array}{l}\text { Fraction of hard coal produced underground for Annex-1 coun- } \\
\text { tries. }\end{array}$ & \\
\hline & & $\begin{array}{l}\text { VAM and degasification emissions as fractions of total emis- } \\
\text { sions recorded for USA, S Africa, Czech Rep., Germany, } \\
\text { Poland, UK, Russia and China. }\end{array}$ & \\
\hline & & Current recovery of degasification gas. & \\
\hline \multirow{2}{*}{$\begin{array}{l}\text { Combustion -fossil and bio } \\
\text { fuels }\end{array}$} & \multirow{2}{*}{ IPCC Tier 1-2 (2006, Vol. 2, 2.16-2.23) } & \multirow{2}{*}{$\begin{array}{l}\text { GAINS model stores country-specific fuel consumption by de- } \\
\text { tailed sector and fuel type for } 162 \text { GAINS regions. }\end{array}$} & $\begin{array}{l}\text { IPCC Tier } 1 \text { default emission factors for mobile sources and non- } \\
\text { residential stationary sources. }\end{array}$ \\
\hline & & & $\begin{array}{l}\text { For residential sources, emission factors specified by fuel and boiler } \\
\text { types. }\end{array}$ \\
\hline \multirow{3}{*}{ Livestock } & \multirow{3}{*}{$\begin{array}{l}\text { Implied ef:s reported to UNFCCC and IPCC } \\
\text { Tier } 1 \text { (2006, Vol.4, Ch. 10) default factors }\end{array}$} & $\begin{array}{l}\text { Reported country-specific emission factors for Annex-1 coun- } \\
\text { tries. }\end{array}$ & \multirow{3}{*}{$\begin{array}{l}\text { IPCC Tier } 1 \text { default emission factors by world region whenever country- } \\
\text { specific information is missing. }\end{array}$} \\
\hline & & $\begin{array}{l}\text { Fractions of liquid and solid manure management applied to } \\
\text { dairy cows, non-dairy cattle and pigs. }\end{array}$ & \\
\hline & & Dairy cow emissions linked to country-specific milk yield & \\
\hline Rice cultivation & IPCC Tier 1-2 (2006, Vol. 4, p. 5.49) & $\begin{array}{l}\text { Country-specific data on applied water regimes, i.e. continu- } \\
\text { ously flooded, intermittently flooded or upland. }\end{array}$ & IPCC default scaling of emission factors for different water regimes \\
\hline $\begin{array}{l}\text { Combustion - agricultural } \\
\text { waste burning }\end{array}$ & IPCC Tier 1 (2006, Vol. 5, p. 5.20) & $\begin{array}{l}\text { Country-specific data on amounts of agricultural waste residu- } \\
\text { als. }\end{array}$ & IPCC Tier 1 default emission factor \\
\hline \multirow{3}{*}{$\begin{array}{l}\text { Biodegradable municipal solid } \\
\text { waste (MSW) }\end{array}$} & \multirow{3}{*}{$\begin{array}{l}\text { IPCC Tier 1-2 (2006, Vol. 5, Ch. 2), Variant of } \\
\text { First-Order Decay method }\end{array}$} & Current MSW generated per person & Missing country-specific info replaced by default assumptions \\
\hline & & Current MSW composition & \multirow{2}{*}{$\begin{array}{l}\text { IPCC default Methane Correction Factor (MCF) for landfilled waste } \\
\text { is } 0.5 \text { for developing countries and } 0.8 \text { for developed countries, unless } \\
\text { otherwise reported to UNFCCC. }\end{array}$} \\
\hline & & $\begin{array}{l}\text { Current treatment of MSW in Annex-1 countries and for a few } \\
\text { non-Annex-1 countries. }\end{array}$ & \\
\hline \multirow[t]{3}{*}{$\begin{array}{l}\text { Biodegradable industrial solid } \\
\text { waste }\end{array}$} & \multirow[t]{3}{*}{$\begin{array}{l}\text { IPCC Tier 1-2 (2006, Vol. 5, Ch. 2), Variant of } \\
\text { First-Order Decay method }\end{array}$} & $\begin{array}{l}\text { Waste generation rates per value added by industry sector for } 31 \\
\text { European countries and European averages as default for other } \\
\text { countries. }\end{array}$ & $\begin{array}{l}\text { IPCC default factors for the content of degradable organic carbon } \\
(\text { DOCm) in different types of waste. }\end{array}$ \\
\hline & & \multirow{2}{*}{$\begin{array}{l}\text { Current treatment of industrial solid waste by industry for } \\
\text { Annex-1 countries. }\end{array}$} & IPCC default factor of 0.5 used for fraction of DOCm that decompose. \\
\hline & & & IPCC default oxidation factor of 0.1 assumed for covered landfills. \\
\hline \multirow{3}{*}{ Domestic wastewater } & \multirow{3}{*}{ IPCC Tier 1-2 (2006, Vol. 5, Ch. 6) } & $\begin{array}{l}\text { Fraction of total population connected to centralized or decen- } \\
\text { tralized wastewater collection. }\end{array}$ & \multirow{3}{*}{$\begin{array}{l}\text { Default MCF assumed for centralized collection is } 0.5 \text { and for decen- } \\
\text { tralized collection } 0.1 \text {. }\end{array}$} \\
\hline & & Country-specific BOD per person. & \\
\hline & & $\begin{array}{l}\text { Current treatment of wastewater (primary/secondary and aero- } \\
\text { bic/anaerobic). }\end{array}$ & \\
\hline & & $\begin{array}{l}\text { Output in tons for relevant food industries, i.e. beer, vegetable } \\
\text { oils, wine, sugar, meat and milk. }\end{array}$ & $\begin{array}{l}\text { For relevant food industries, IPCC default rates for COD content in } \\
\text { wastewater per ton of product. }\end{array}$ \\
\hline Industrial wastewater & IPCC Tier 1-2 (2006, Vol.5, Ch. 6) & & $\begin{array}{l}\text { For pulp and paper industry, typical amounts of wastewater generated } \\
\text { and COD content for different types of processes. }\end{array}$ \\
\hline & & $\begin{array}{l}\text { Output by type of production process for pulp and paper indus- } \\
\text { try. }\end{array}$ & $\begin{array}{l}\text { For organic chemical industry, typical wastewater generation rates cal- } \\
\text { culated for Europe per value added and extended to rest of the world. }\end{array}$ \\
\hline & & & $\begin{array}{l}\text { For organic chemical industry, IPCC default rates for COD content in } \\
\text { wastewater. }\end{array}$ \\
\hline
\end{tabular}

technologies that are fairly well known makes the assessment of the mitigation potential conservative rather than optimistic.

Table 3 presents a list of $\mathrm{CH}_{4}$ mitigation options included in the GAINS model with specifications of how maximum technically feasible applications are defined. For detailed information about the sources and references used for assumptions about removal potentials and costs, please refer to the sector descriptions in the Supplement. 
Table 3. $\mathrm{CH}_{4}$ mitigation measures in the GAINS model.

\begin{tabular}{|c|c|}
\hline Emission source sector & Definition of $\mathrm{CH}_{4}$ mitigation measures for max technically feasible mitigation potential \\
\hline \multirow[t]{2}{*}{ Oil \& gas production } & $\begin{array}{l}\text { Recovery and utilization of vented associated gas assuming at least } 95 \% \text { of associated gas now } \\
\text { flared or vented can be recovered and utilized. Costs reflect costs for recovery, LNG conversion } \\
\text { when needed and transportation by pipeline or ship to EU border. }\end{array}$ \\
\hline & $\begin{array}{l}\text { Reducing unintended leakage from wells and temporary storage in developing/transitional } \\
\text { countries to levels currently observed in developed countries. }\end{array}$ \\
\hline $\begin{array}{l}\text { Long-distance gas } \\
\text { transmission }\end{array}$ & $\begin{array}{l}\text { Reduced leakage rates everywhere to levels currently observed in W Europe, } \mathrm{N} \text { America and } \\
\text { Japan, i.e. about } 10 \mathrm{~kg} \mathrm{CH}_{4} \mathrm{bcm}^{-1} \mathrm{~km}^{-1} \text {. }\end{array}$ \\
\hline $\begin{array}{l}\text { Gas distribution } \\
\text { networks }\end{array}$ & Replacement of grey cast iron pipes with PE or PVC networks. \\
\hline \multirow[t]{2}{*}{ Coal mining } & $\begin{array}{l}\text { Pre-mine degasification with gas recovery and utilization applicable on both surface and under- } \\
\text { ground coal mines. Up to } 90 \% \text { of current degasification emissions assumed recoverable. Costs } \\
\text { includes recovery of gas, and for surface mines and mildly gassy underground coal seams, up- } \\
\text { grading costs are included. }\end{array}$ \\
\hline & $\begin{array}{l}\text { Oxidation of ventilation air methane (VAM) on underground mines applicable to } 50 \% \text { of current } \\
\text { VAM emissions in all countries except S. Africa and India and with possible extension to } 70 \% \\
\text { if combined with improved ventilation air systems. }\end{array}$ \\
\hline Combustion & Ban on open burning of agricultural waste. \\
\hline \multirow[t]{2}{*}{ Livestock } & Diet changes applicable to indoor fed cows and cattle. \\
\hline & $\begin{array}{l}\text { Farm-scale anaerobic digestion of manure from cows, cattle and pigs on large farms with liquid } \\
\text { manure management systems. Household-scale digestors applicable to up to } 30 \% \text { of manure } \\
\text { from cows, cattle and pigs in developing countries. }\end{array}$ \\
\hline Rice cultivation & $\begin{array}{l}\text { Combined option of intermittent aeration of continuously flooded fields and use of alternative } \\
\text { hybrids and sulphate amendments. }\end{array}$ \\
\hline \multirow{5}{*}{$\begin{array}{l}\text { Municipal solid waste- } \\
\text { food \& garden residues, } \\
\text { paper, and wood }\end{array}$} & Full source separation of waste and no future landfill of untreated biodegradable waste. \\
\hline & $\begin{array}{l}\text { Treatment of up to } 90 \% \text { of household food and garden waste in composts or in anaerobic } \\
\text { digesters with biogas recovery and utilization. }\end{array}$ \\
\hline & Recycling of up to $90 \%$ of household paper waste. \\
\hline & Incineration with energy recovery of up to $90 \%$ of household wood waste. \\
\hline & $\begin{array}{l}\text { Landfill gas recovery applied to capture emissions from historical deposition of biodegradable } \\
\text { waste. }\end{array}$ \\
\hline \multirow{3}{*}{$\begin{array}{l}\text { Industrial solid waste- } \\
\text { food, pulp \& paper, and } \\
\text { wood industry }\end{array}$} & Food industry: treatment of waste in anaerobic digesters with biogas recovery and utilization. \\
\hline & Pulp \& paper industry: recovery of black liqour for energy utilization. \\
\hline & $\begin{array}{l}\text { Wood industry: max recycling of waste for chipboard production with residuals being inciner- } \\
\text { ated for energy utilization. }\end{array}$ \\
\hline Domestic wastewater & $\begin{array}{l}\text { Upgrade of current primary treatment systems to anaerobic treatment with biogas recovery and } \\
\text { utilization. }\end{array}$ \\
\hline $\begin{array}{l}\text { Industrial wastewater- } \\
\text { food, pulp \& paper, and } \\
\text { organic chemical } \\
\text { industry }\end{array}$ & $\begin{array}{l}\text { Upgrade of current treatment systems to two-stage anaerobic treatment with biogas recovery } \\
\text { followed by aerobic treatment. }\end{array}$ \\
\hline
\end{tabular}



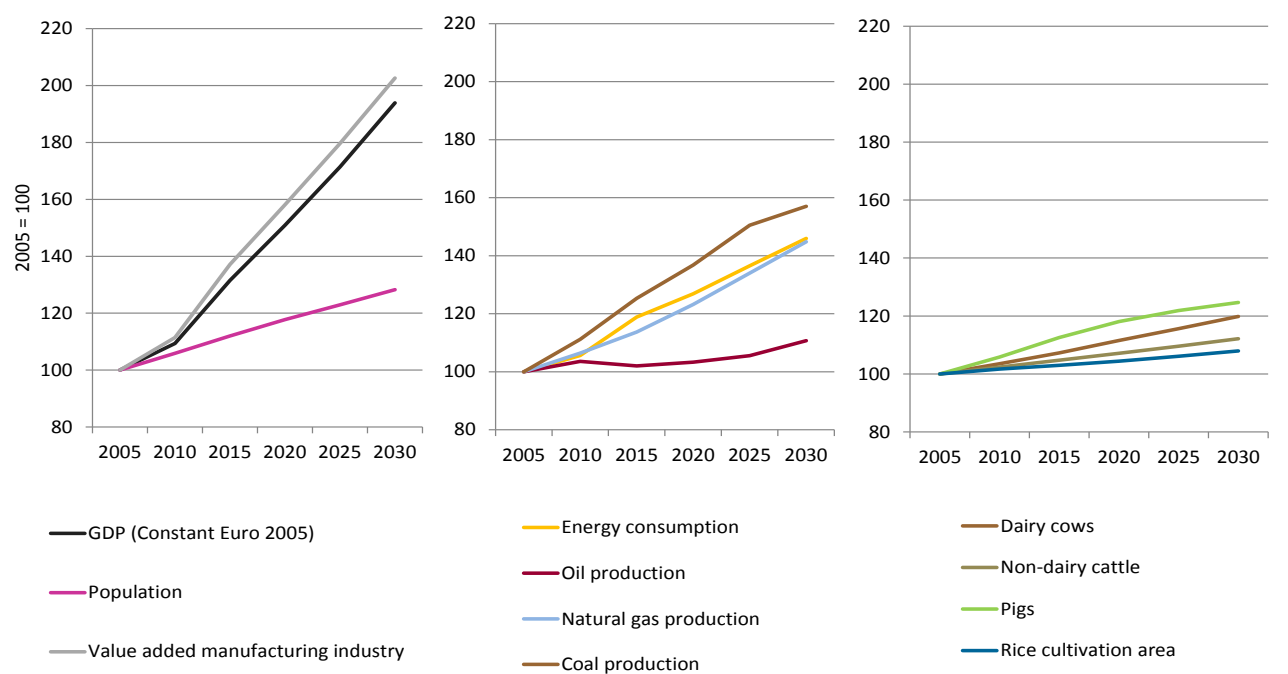

Fig. 1. Global development 2005 to 2030 in major drivers for $\mathrm{CH}_{4}$ emissions entering model estimations from external sources (IEA-WEO, 2009; FAO, 2003; CAPRI model, 2009).

Table 4. Gas prices in the IEA-WEO (2009) Reference scenario in Euro $\mathrm{GJ}^{-1}$.

\begin{tabular}{lrrrrrr}
\hline & 2005 & 2010 & 2015 & 2020 & 2025 & 2030 \\
\hline Europe & 3.95 & 5.29 & 7.20 & 8.32 & 9.01 & 9.64 \\
North America & 5.94 & 3.73 & 5.02 & 6.10 & 6.90 & 7.81 \\
Pacific & 4.50 & 6.23 & 8.19 & 9.46 & 10.20 & 10.91 \\
\hline
\end{tabular}

\subsubsection{Mitigation costs}

$\mathrm{CH}_{4}$ mitigation costs per unit of activity are in GAINS calculated as the sum of investment costs, labour costs, non-labour operation and maintenance costs, cost-savings due to gas or energy recovery, and non-energy cost savings. The annual cost per unit of activity of applying technology $m$ in country $i$ and year $t$ is defined as:

$$
\begin{aligned}
C_{i t m} & =I_{i m}\left[\frac{(1+r)^{T_{m}} \times r}{(1+r)^{T_{m}}-1}\right]+M_{i m}+\left(L_{i m} \times W_{i t} \times w_{i s}\right) \\
& -S_{i m}-0.75\left(E_{i m} \times p_{i t}^{\text {electr }}\right)-\left(G_{i m} \times p_{i t}^{\mathrm{gas}}\right)
\end{aligned}
$$

where $I_{i m}$ is the non-annualized investment cost for technology $m$ in country $i$, i.e. the upfront investment cost, $\left[\frac{(1+r)^{T_{m}} \times r}{(1+r)^{T_{m}}-1}\right]$ is the factor by which investment costs are annualized using discount rate $r$ and a technology-specific lifetime of $T_{m}$ years, $M_{i m}$ is the annual operation and maintenance cost for technology $m, L_{i m}$ is the fraction of annual work hours for operating technology $m, W_{i t}$ is the annual average wage in country $i$ in year $t, w_{i s}$ is a country-specific wage adjustment factor for type of sector $s$ (agriculture or manufacturing industry), $S_{i m}$ is the sum of non-energy annual cost-savings, $E_{i m}$ is the amount of energy recovered and utilized as electricity or heat, $p_{i t}^{\text {electr }}$ is the electricity price in country $i$ in year $t, G_{i m}$ is the amount of gas recovered, and $p_{i t}^{\text {gas }}$ is the gas price in country $i$ in year $t$.

The unit costs are expressed in constant 2005 Euros per unit of activity. Depending on the sector, the unit mitigation cost is expressed in e.g. Euro per cow, Euro per GJ oil produced or Euro per ton waste generated.

Country and sector specific annual average wages are taken from LABORSTA (ILO, 2010) for historical years. Agriculture and manufacturing industry wages as fractions of the average annual wage were derived on a country-specific basis taking the average for 2005-2008 and keeping the fractions constant for future years. Projections for agriculture and manufacturing industry wages are assumed to follow growth in value added in respective sector (IEA-WEO, 2009).

In the GAINS estimation of $\mathrm{CH}_{4}$ mitigation costs, energy recovery with utilization assumes half of recovered energy is utilized as heat and half converted to electricity. The price of heat is taken to be half the electricity price, i.e. the opportunity cost saving of recovering energy is multiplied by a factor 0.75 .

Gas recovery refers to recovered gas of an upgraded quality of 97 percent $\mathrm{CH}_{4}$. For some mitigation options, e.g. when biogas is recovered from anaerobic digestion or landfills, upgrading from 60 to 97 percent $\mathrm{CH}_{4}$ is necessary for supplying the gas to the grid (Persson, 2003). Costs for upgrading gas have been included in investment costs.

Gas prices with projections are taken from the IEA-WEO (2009) Reference scenario as presented in Table 4. The price of electricity has been derived from the price of natural gas using the investment and operation costs of converting gas to electricity in a natural gas combined cycle power plant taken from OECD/IEA (2005). From this cost and when expressing the prices of electricity and gas in per unit of GJ, the 
Table 5. Regional aggregations of $\mathrm{CH}_{4}$ emission estimates in GAINS.

\begin{tabular}{ll}
\hline World region & GAINS $\mathrm{CH}_{4}$ regions \\
\hline Africa & $\begin{array}{l}\text { Egypt, South Africa, North Africa (includes Algeria, Morocco, Libya, Tunisia, Sudan), and } \\
\text { Other Africa (includes all other African countries) }\end{array}$ \\
\hline China & China \\
\hline India & India \\
\hline Asia -rest & $\begin{array}{l}\text { Afghanistan, Armenia, Azerbaijan, Bangladesh, Bhutan, Brunei, Cambodia, Former Soviet } \\
\text { Union States (includes Tadjikistan, Turkmenistan and Uzbekistan), Gerogia, Indonesia, Japan, }\end{array}$ \\
& $\begin{array}{l}\text { Kazakhstan, Kyrgizistan, Nepal, North Korea, Laos, Malaysia, Mongolia, Myanmar, Pakistan, } \\
\text { Philippines, Singapore, South Korea, Sri Lanka, Taiwan, Thailand and Vietnam }\end{array}$ \\
\hline Australia\&NZ & Australia and New Zeeland \\
\hline US\&Canada & Canada and United States \\
\hline L. America & $\begin{array}{l}\text { Argentina, Brazil, Chile, Mexico, Other Latin America (includes all other countries in Central- } \\
\text { and Latin America and the Caribbean) }\end{array}$ \\
\hline EU-27 & $\begin{array}{l}\text { Austria, Belgium, Bulgaria, Cyprus, Czech Republic, Denmark, Estonia, Finland, France, Ger- } \\
\text { many, Greece, Hungary, Ireland, Italy, Latvia, Lithuania, Luxembourg, Malta, Netherlands, } \\
\text { Poland, Portugal, Romania, Slovakia, Slovenia, Spain, Sweden, United Kingdom }\end{array}$ \\
\hline Europe - rest & $\begin{array}{l}\text { Albania, Belarus, Bosnia-Herzegovina, Croatia, Iceland, Macedonia, Moldova, Norway, Serbia- } \\
\text { Montenegro, Switzerland, Turkey, Ukraine }\end{array}$ \\
\hline Middle East & $\begin{array}{l}\text { Middle East (includes Bahrain, Kuwait, Oman, Qatar, Saudi Arabia, UAE, Yemen, Gaza, Israel, } \\
\text { Iran Iraq, Jordan, Lebanon and Syria) }\end{array}$ \\
\hline Russian Federation \\
\hline
\end{tabular}

following general approximation of the link between the gas and the electricity prices was constructed:

$p_{i t}^{\text {electr }}=3+2 p_{i t}^{\text {gas }}$.

The total mitigation cost in sector $s$ in country $i$ and year $t$ when technology $m$ is applied to application rate Appl $_{i t s m}$ is defined as:

$\mathrm{TC}_{i t s}=\sum_{m}\left[A_{i t s} \cdot C_{i t m} \cdot \mathrm{Appl}_{i t s m}\right]$

where $A_{i t s}$ is the activity level, $C_{i t m}$ is the cost per unit of activity and $\sum_{m} \mathrm{Appl}_{i t s m}=1$.

The average cost of mitigation when applying technology $m$ on sector $s$ in country $i$ and year $t$, is defined as the additional cost imposed on the sector in comparison with the cost already invested on mitigation in the baseline. The additional cost is then divided by the additional emission reduction attained when applying technology $m$ in sector $s$, i.e.

$\mathrm{AC}_{i t s}=\frac{\mathrm{TC}_{i t s}^{\mathrm{Max}}-\mathrm{TC}_{i t s}^{\text {Baseline }}}{E_{i t s}^{\mathrm{Max}}-E_{i t s}^{\text {Baseline }}}$.

Hence, if mitigation has already been adopted in the baseline in response to current legislation, the average cost reflects the additional cost of extending mitigation beyond current legislation. When no mitigation has been adopted in the baseline, the average cost reflects the cost of moving from no control to maximum mitigation in the sector.

The marginal mitigation cost curve on a global or world region scale is built up by the country and year-specific average cost estimates for extending adoption of mitigation technology in each sector.

\subsubsection{Social and private cost perspectives}

An important feature of splitting the unit mitigation costs for $\mathrm{CH}_{4}$ in GAINS into different cost items is that it allows for specifying costs from different investor perspectives. From an investor's point of view, costs are not absolute but relative to a set of alternative costs and benefits available to the investor in a certain moment in time. The subjective perspective of the investor is therefore decisive for investment decisions in general as well as for mitigation investments. To reflect some of the effects of differences in investor perspectives, two different cost perspectives are defined: a "social" and a "private".

The social cost perspective refers to a social planner or public investor, who optimizes costs and benefits over a longer future time horizon and is able to accommodate risks better than a private investor. The social investor is assumed 


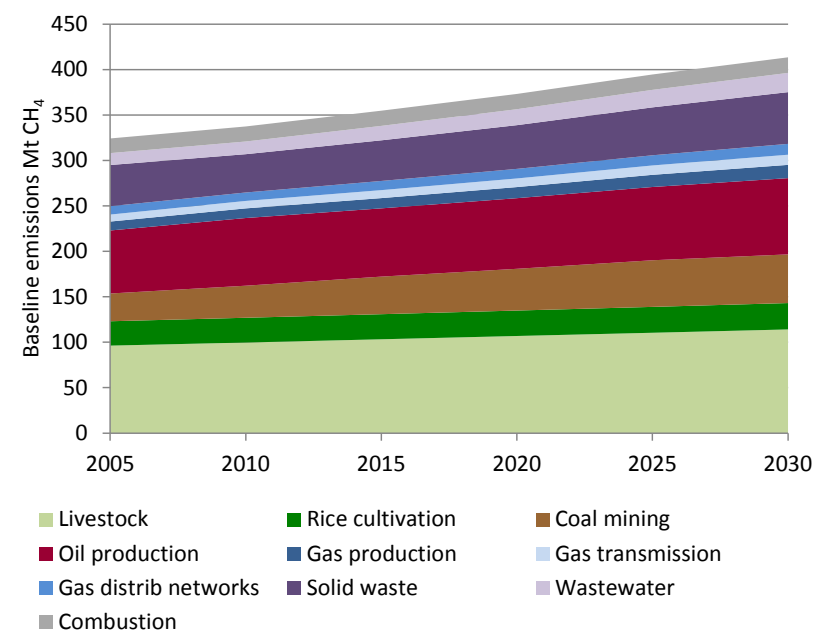

Fig. 2. Global anthropogenic $\mathrm{CH}_{4}$ baseline emissions 2005 to 2030.

to apply a discount rate of four percent as a reflection of the long-term social opportunity cost of capital. The entire lifetime of installed mitigation technology, which for $\mathrm{CH}_{4}$ mitigation technology included in GAINS varies from two to twenty years, is regarded in the cost analysis. Finally, the expected increase in the future gas price, here foreseen by the IEA-WEO (2009) Reference scenario, is assumed fully anticipated in the social planner's investment decision.

The private investor is assumed to have an interest in shortterm profits at a minimum of uncertainty. In this cost perspective, the discount rate reflecting the private opportunity cost of capital is taken to be ten percent and the equipment lifetime is only considered up to maximum ten years. Due to high uncertainty about the future gas price level, investors are expected to heavily discount potential future gains from increases in the gas price to the extent that only observed fuel price levels are anticipated in the investment decisions today. The same type of unwillingness to invest in mitigation under uncertainty is in the economics literature often regarded as the expected response of rational investors to uncertainty in future carbon price levels (Brunner et al., 2012).

\subsection{Geographic coverage of $\mathrm{CH}_{4}$ in GAINS}

The geographic coverage of $\mathrm{CH}_{4}$ emission estimates in the GAINS model is global with the world divided into 83 regions as specified in Table 5. Emissions, mitigation potentials and costs are calculated for each of the 83 regions, however to display results, the regions are aggregated into ten world regions as shown in Table 5.

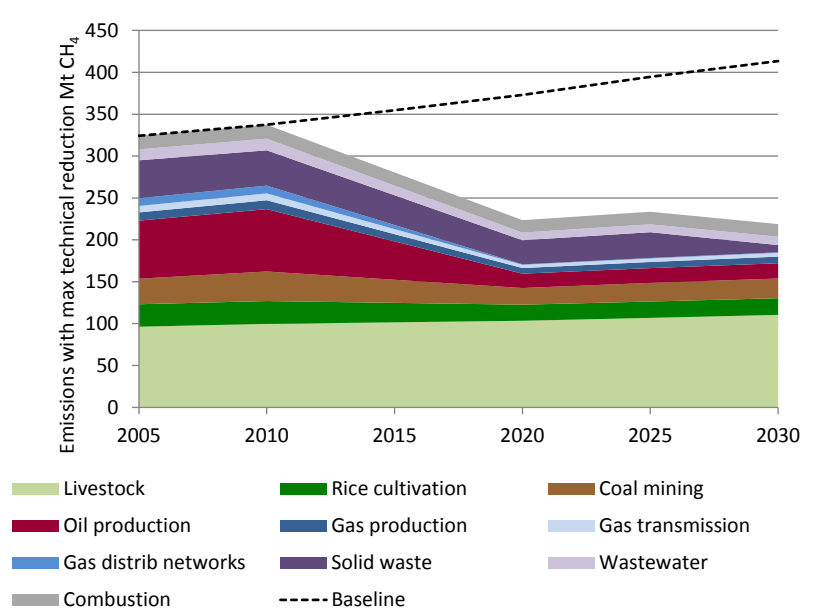

Fig. 3. Global anthropogenic $\mathrm{CH}_{4}$ emissions with max implementation of available mitigation technology 2005 to 2030 .

\section{Results}

\subsection{Global $\mathrm{CH}_{4}$ emissions and mitigation potentials}

Global anthropogenic emissions of $\mathrm{CH}_{4}$ are estimated at $323 \mathrm{Mt}$ in 2005 and expected to increase by 28 percent to $414 \mathrm{Mt}$ in 2030 when assuming no further implementation of control measures than those currently adopted or prescribed by implemented legislation. Figure 2 illustrates the expected development in global baseline emissions and Table 6 summarizes the findings quantitatively. Fossil fuel extraction and use contribute $131 \mathrm{Mt} \mathrm{CH}_{4}$ or 41 percent of global $\mathrm{CH}_{4}$ emissions in 2005. Until 2030 emissions from this sector are expected to grow by 37 percent, primarily due to an expected increase in production and use of coal in China. Agriculture sources contribute $126 \mathrm{Mt}$ in 2005 with an expected increase by 16 percent until 2030 . Solid waste and wastewater sectors contribute $57 \mathrm{Mt} \mathrm{CH}_{4}$ to emissions in 2005 with an expected increase by 36 percent until 2030, much driven by an increase in emissions from food industry waste and wastewater. Com-

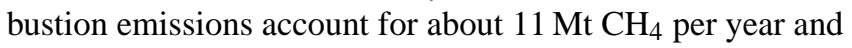
are expected to remain rather stable in the future.

The full technical mitigation potential for $\mathrm{CH}_{4}$ in 2030 is estimated at $195 \mathrm{Mt} \mathrm{CH}_{4}$, i.e. 47 percent below baseline or 33 percent below the 2005 emission level. Figure 3 shows how maximum implementation of available mitigation technology has immediate effect in all sectors except solid waste, where a slow decomposition of waste deposited to landfills postpones effects on emissions by an assumed ten years for fast degrading waste and twenty years for slow degrading waste (see Supplement for further details). More than 60 percent of the technical mitigation potential in 2030 can be realized in fossil fuel extraction, about 30 percent in waste and wastewater sectors and only eight percent in agriculture. 
Table 6. Global $\mathrm{CH}_{4}$ emissions and technical mitigation potentials in 2030.

\begin{tabular}{|c|c|c|c|c|}
\hline \multirow[t]{2}{*}{ Emission source sector } & \multirow[t]{2}{*}{ Control measure } & $\begin{array}{r}\text { Baseline } \\
2005\end{array}$ & $\begin{array}{r}\text { Baseline } \\
2030\end{array}$ & $\begin{array}{l}\text { Max technical } \\
\text { reduction } 2030\end{array}$ \\
\hline & & $\mathrm{Mt} \mathrm{CH}_{4}$ & $\mathrm{Mt} \mathrm{CH}_{4}$ & 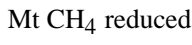 \\
\hline \multirow[t]{2}{*}{ Non-dairy cattle } & Liquid manure: max implementation of anaerobic digestion & 0.2 & 0.2 & 0.1 \\
\hline & Ent. fermentation: diet changes indoor fed cattle & 50.3 & 57.2 & 0.5 \\
\hline \multirow[t]{2}{*}{ Dairy cows } & Liquid manure: max implementation of anaerobic digestion & 0.9 & 0.9 & 0.2 \\
\hline & Ent. fermentation: diet changes indoor fed cattle & 17.3 & 20.3 & 1.0 \\
\hline Pigs & Max implementation of anaerobic digestion of liquid manure & 5.6 & 6.8 & 1.9 \\
\hline Other livestock & No mitigation option identified & 22.1 & 29.0 & 0.0 \\
\hline Rice cultivation: continuously flooded & Combined: aeration, alt. hybrids and sulphate amendments & 19.7 & 21.5 & 7.2 \\
\hline Rice cultivation: intermittently aerated & Combined: alt. hybrids and sulphate amendments & 7.1 & 7.5 & 1.9 \\
\hline Agricultural waste burning & Ban & 3.1 & 3.6 & 1.9 \\
\hline MSW food\&garden waste & Max separation and treatment, no landfill of biodegr. waste & 10.3 & 11.8 & 9.2 \\
\hline MSW paper waste & Max separation and treatment, no landfill of biodegr. waste & 16.7 & 18.2 & 15.2 \\
\hline MSW wood waste & Max separation and treatment, no landfill of biodegr. waste & 5.0 & 5.5 & 5.5 \\
\hline Food industry solid waste & Anaerobic digestion with gas recovery and utilization & 9.0 & 17.6 & 15.0 \\
\hline Pulp\&paper ind solid waste & Max recovery and utilization of black liquor & 0.2 & 0.4 & 0.3 \\
\hline Textile industry solid waste & Max recovery and utilization & 1.1 & 1.2 & 1.2 \\
\hline Wood industry solid waste & Max recovery and utilization & 2.0 & 2.2 & 1.8 \\
\hline Domestic wastewater & Upgrade to anaerobic treatm with gas recovery and utilization & 7.9 & 9.2 & 1.9 \\
\hline Food industry wastewater & Upgrade to anaerobic treatm with gas recovery and utilization & 2.0 & 4.7 & 3.9 \\
\hline Pulp\&paper ind wastewater & Upgrade to anaerobic treatm with gas recovery and utilization & 2.0 & 4.9 & 3.5 \\
\hline Org chemical ind wastewater & Upgrade to anaerobic treatm with gas recovery and utilization & 1.2 & 2.4 & 2.0 \\
\hline Coal mining - brown coal: pre-mining & Pre-mining degasification & 0.2 & 0.3 & 0.3 \\
\hline Coal mining - brown coal: mining (VAM) & No mitigation option identified & 0.5 & 0.7 & 0.0 \\
\hline Coal mining - brown coal: post-mining & No mitigation option identified & 0.1 & 0.1 & 0.0 \\
\hline Coal mining - hard coal: pre-mining & Pre-mining degasification & 7.6 & 13.9 & 12.1 \\
\hline Coal mining - hard coal: mining (VAM) & Ventilation air oxidizer with improved ventilation systems & 15.6 & 26.7 & 17.6 \\
\hline Coal mining - hard coal: post-mining & No mitigation option identified & 6.6 & 11.9 & 0.0 \\
\hline Oil production - associated gas & Recovery and utilization of vented associated gas & 55.9 & 68.9 & 60.3 \\
\hline Oil production - leakage & Good practice measures to reduce unintended leakage & 13.4 & 15.0 & 5.3 \\
\hline Oil transportation and refining & Good practice measures to reduce leakage & 0.2 & 0.2 & 0.1 \\
\hline Gas production - associated gas & Recovery and utilization of vented associated gas & 1.8 & 2.9 & 2.5 \\
\hline Gas production - leakage & Good practice measures to reduce unintended leakage & 8.1 & 11.7 & 4.1 \\
\hline Oil and gas production - associated gas flaring & Linked to mitigation of associated gas emissions & 2.1 & 2.6 & 0.0 \\
\hline Long-distance gas transmission & Leakage reduced to $10 \mathrm{~kg} \mathrm{CH}_{4} /\left(\mathrm{bcm}^{*} \mathrm{~km}\right)$ & 7.7 & 11.2 & 6.7 \\
\hline Gas distr. networks (residential) & Replacement of grey cast iron pipes and doubling of control & 4.9 & 6.3 & 6.1 \\
\hline Gas distr. networks (non-residential) & Replacement of grey cast iron pipes and doubling of control & 4.3 & 5.6 & 5.2 \\
\hline Combustion - fossil fuels & No mitigation option identified & 2.4 & 2.5 & 0.0 \\
\hline Combustion - biomass fuels & No mitigation option identified & 8.3 & 8.2 & 0.0 \\
\hline Livestock \& Rice cultivation & & 123.3 & 143.3 & 12.8 \\
\hline Waste \& Wastewater & & 57.4 & 78.0 & 59.4 \\
\hline Fuel production, transportation \& energy use & & 139.6 & 188.6 & 120.4 \\
\hline Burning of agr. waste & & 3.1 & 3.6 & 1.9 \\
\hline Total & & 323.4 & 413.6 & 194.6 \\
\hline
\end{tabular}

Figures 4 and 5 show the distribution of baseline 2030 emissions and technical mitigation potentials by world region. China and Latin \& Central America are expected to be the two dominating emitters in 2030. China because of extensive extraction and use of coal as fuel and Latin \& Central America because of extensive cattle raising and heavy oil extraction. The technical mitigation potential in 2030 is primarily found in world regions with extensive fossil fuel extraction.

\subsection{Mitigation costs}

Marginal mitigation cost curves for controlling global anthropogenic methane emissions in 2020 and 2030 when using social and private cost perspectives are illustrated in Figs. 6 and 7. With a private cost perspective (blue line), expected baseline emissions are reduced at a considerably higher cost than with a social cost perspective (red line). With a social cost perspective the marginal cost for implementing the full technical mitigation potential in 2030 is on average -151 Euro ${ }^{-1} \mathrm{CH}_{4}$, i.e. a net marginal profit corresponding to about 3.5 Euro ${ }^{-1} \mathrm{CO}_{2}$ eq. With a private cost perspective, 
Table 7. Costs for global $\mathrm{CH}_{4}$ technical mitigation potentials when estimated from social and private cost perspectives.

\begin{tabular}{|c|c|c|c|c|c|c|c|c|}
\hline \multirow[t]{4}{*}{ Emission source sector } & \multirow[t]{4}{*}{ Control measure } & \multirow{3}{*}{$\begin{array}{l}\text { Max technical } \\
\text { reduction } 2030\end{array}$} & \multicolumn{6}{|c|}{ Global costs max reduction 2030} \\
\hline & & & \multicolumn{3}{|c|}{ Social cost perspective } & \multicolumn{3}{|c|}{ Private cost perspective } \\
\hline & & & $\begin{array}{r}\text { Marginal cost } \\
\text { (weighted average) }\end{array}$ & Regional range & Total cost & $\begin{array}{r}\text { Marginal cost } \\
\text { (weighted average) }\end{array}$ & Regional range & Total cost \\
\hline & & Mt $\mathrm{CH}_{4}$ reduced & Euro ${ }^{-1} \mathrm{CH}_{4}$ & Euro $\mathrm{t}^{-1} \mathrm{CH}_{4}$ & $10^{9}$ Euro & Euro ${ }^{-1} \mathrm{CH}_{4}$ & Euro $\mathrm{t}^{-1} \mathrm{CH}_{4}$ & $10^{9}$ Euro \\
\hline \multirow[t]{2}{*}{ Non-dairy cattle } & Liquid manure: max implementation of anaerobic digestion & 0.1 & 6988 & 1712 to 51877 & 0.5 & 15262 & 8895 to 84828 & 1.1 \\
\hline & Ent. fermentation: diet changes indoor fed cattle & 0.5 & 1080 & 933 to 1255 & 0.6 & 1080 & 933 to 1255 & 0.6 \\
\hline \multirow[t]{2}{*}{ Dairy cows } & Liquid manure: max implementation of anaerobic digestion & 0.2 & -76 & -912 to 950 & 0.0 & 3306 & 2756 to 4779 & 0.6 \\
\hline & Ent. fermentation: diet changes indoor fed cattle & 1.0 & 884 & 353 to 1614 & 0.9 & 884 & 353 to 1614 & 0.9 \\
\hline Pigs & Liquid manure: max implementation of anaerobic digestion & 1.9 & -1864 & -3059 to -1244 & -3.5 & -143 & -1075 to 111 & -0.3 \\
\hline Rice - continuously flooded & Combined: aeration, alt hybrids and sulphate amendments & 7.2 & 361 & 103 to 1847 & 2.6 & 361 & 103 to 1847 & 2.6 \\
\hline Rice - intermittently aerated & Combined: alt hybrids and sulphate amendments & 1.9 & 340 & 338 to 342 & 0.7 & 340 & 338 to 342 & 0.7 \\
\hline Agricultural waste burning & Ban & 1.9 & 0 & no range & 0.0 & 0 & no range & 0.0 \\
\hline MSW food\&garden waste & Source separation and treatment, no landfill of biodegr. waste & 9.2 & 2081 & 640 to 6875 & 19.2 & 4014 & 1447 to 9779 & 37.0 \\
\hline MSW paper waste & Source separation and treatment, no landfill of biodegr. waste & 15.2 & -3279 & -5139 to 1023 & -49.9 & -2484 & -4235 to 401 & -37.8 \\
\hline MSW wood waste & Source separation and treatment, no landfill of biodegr. waste & 5.5 & -2097 & -3779 to -266 & -11.6 & 1482 & 492 to 3396 & 8.2 \\
\hline Food industry solid waste & Anaerobic digestion w gas recovery and utilization & 15.0 & 261 & -146 to 318 & 3.9 & 1202 & 628 to 1570 & 18.0 \\
\hline Pulp\&paper ind solid waste & Recovery and utilization of black liquor & 0.3 & -29782 & -38602 to -15441 & -9.4 & -21392 & -30041 to -12016 & -6.8 \\
\hline Textile industry solid waste & Energy recovery & 1.2 & -3639 & -4932 to -1481 & -4.3 & 2219 & 1066 to 2665 & 2.6 \\
\hline Wood industry solid waste & Recycling and energy recovery & 1.8 & -2736 & -3293 to -1325 & -5.0 & -1574 & -1894 to -763 & -2.9 \\
\hline Domestic wastewater & Upgrade to anaerobic treatm $w$ gas recovery and utilization & 1.9 & 2996 & 1716 to 4831 & 5.8 & 7628 & 4673 to 11831 & 14.7 \\
\hline Food industry wastewater & Upgrade to anaerobic treatm $w$ gas recovery and utilization & 3.9 & -227 & -4103 to 390 & -0.9 & 2039 & 1735 to 3411 & 7.9 \\
\hline Pulp\&paper ind wastewater & Upgrade to anaerobic treatm $w$ gas recovery and utilization & 3.5 & -652 & -3055 to 1649 & -2.3 & 1725 & 264 to 4327 & 6.0 \\
\hline Org chemical ind wastewater & Upgrade to anaerobic treatm $w$ gas recovery and utilization & 2.0 & 51 & -2505 to 379 & 0.1 & 1665 & 1638 to 1669 & 3.3 \\
\hline Coal mining - brown coal: pre-mining & $\begin{array}{l}\text { Pre-mining degasification } \\
\text { (n) }\end{array}$ & 0.3 & -52 & -167 to -6 & 0.0 & 315 & 195 to 486 & 0.1 \\
\hline Coal mining - hard coal: pre-mining & Pre-mining degasification & 12.1 & 957 & -143 to 7523 & 11.6 & 1339 & 139 to 7942 & 16.3 \\
\hline Coal mining - hard coal: mining (VAM) & Ventilation air oxidizer $w$ improved ventilation systems & 17.6 & 163 & 97 to 1486 & 2.9 & 191 & 185 to 1816 & 3.4 \\
\hline Oil production - associated gas & Recovery and utilization of vented associated gas & 60.3 & -109 & -778 to 358 & -6.6 & 1278 & 569 to 1716 & 77.1 \\
\hline Oil production - leakage & Good practice measures to reduce unintended leakage & 5.3 & 1289 & 935 to 6417 & 6.9 & 1289 & 935 to 6417 & 6.9 \\
\hline Oil transportation and refining & Good practice measures to reduce leakage & 0.1 & 240 & 236 to 243 & 0.0 & 373 & 369 to 376 & 0.0 \\
\hline Gas production - associated gas & Recovery and utilization of vented associated gas & 2.5 & -490 & -515 to -451 & -1.2 & -132 & -135 to -130 & -0.3 \\
\hline Gas production - leakage & Good practice measures to reduce unintended leakage & 4.1 & 1068 & 799 to 12009 & 4.4 & 1382 & 1081 to 12291 & 5.7 \\
\hline Long-distance gas transmission & Leakage reduced to $10 \mathrm{~kg} \mathrm{CH}_{4} \mathrm{bcm}^{-1} \mathrm{~km}^{-1}$ & 6.7 & -191 & -395 to 4086 & -1.3 & 372 & -29 to 8785 & 2.5 \\
\hline Gas distr. networks (residential) & Replacement of grey cast iron pipes & 6.1 & 541 & -58 to 1289 & 3.3 & 2141 & 898 to 3893 & 13.0 \\
\hline Gas distr. networks (non-residential) & Replacement of grey cast iron pipes & 5.2 & 561 & -73 to 1231 & 2.9 & 2189 & 902 to 3842 & 11.5 \\
\hline Livestock \& Rice cultivation & & 12.8 & 129 & -3059 to 51877 & 1.7 & 480 & -1075 to 84828 & 6.1 \\
\hline Waste \& Wastewater & & 59.4 & -914 & -39602 to 6875 & -54.3 & 843 & -30041 to 9779 & 50.1 \\
\hline Fossil fuel extraction and use & & 120.4 & 190 & -778 to 12009 & 22.9 & 1129 & -135 to 12291 & 136.0 \\
\hline Burning of agricultural waste & & 1.9 & 0 & no range & 0 & 0 & no range & 0 \\
\hline Total & & 195 & -153 & -683 to 829 & -30 & 988 & 568 to 2344 & 192 \\
\hline
\end{tabular}

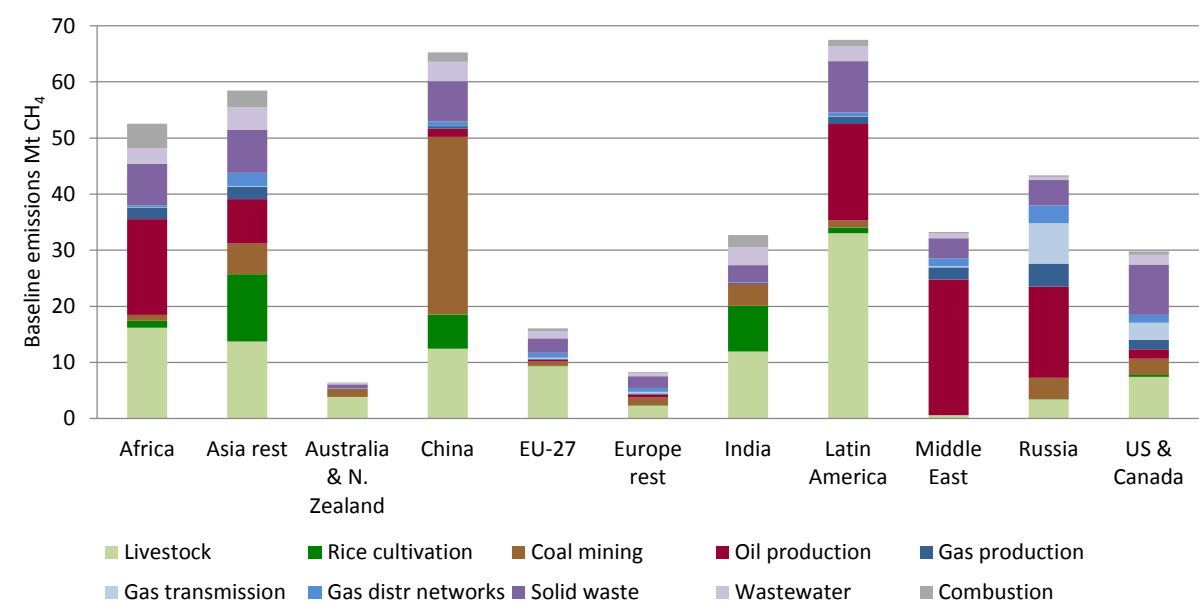

Fig. 4. $\mathrm{CH}_{4}$ baseline emissions in 2030 by sector and world region.

the corresponding picture changes to 988 Euro $^{-1} \mathrm{CH}_{4}$, i.e. a net marginal cost of about 40 Euro $\mathrm{t}^{-1} \mathrm{CO}_{2}$ eq. Hence, with a social cost perspective the technically feasible cut by half in global $\mathrm{CH}_{4}$ emissions can be expected to pay for itself, while with a private cost perspective the cost can be regarded as considerable.

In Fig. 7 the effects on the global $\mathrm{CH}_{4}$ mitigation cost curve of each of the different assumptions made for defining the private cost perspective have been separated out. Starting from the social perspective cost curve and adding only the assumption about not anticipating future gas price increases in the investment decision, has a significant effect on marginal mitigation costs for low cost options. This is the cost range where most options involving recovery of gas can be found. For more expensive options, the higher private interest rate and the shorter investment time horizon play more important roles in the marginal cost than the level of the gas price.

A detailed summary of the costs by implemented mitigation technology is presented in Table 7 with illustrations of global sector mitigation cost curves in Fig. 8. The single most effective mitigation option both in terms of removed emissions and social costs is recovery of associated gas from oil production. With a social cost perspective, this option is estimated to bring a net profit of about 6.6 billion Euro per year 


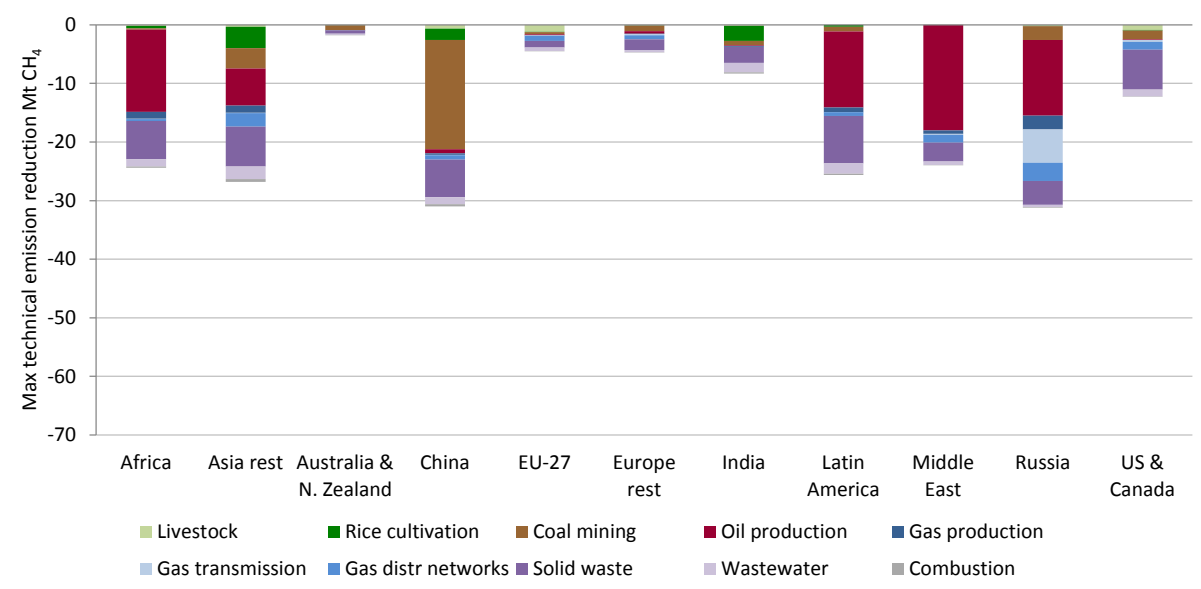

Fig. 5. $\mathrm{CH}_{4}$ maximum technical reduction in 2030 by sector and world region.
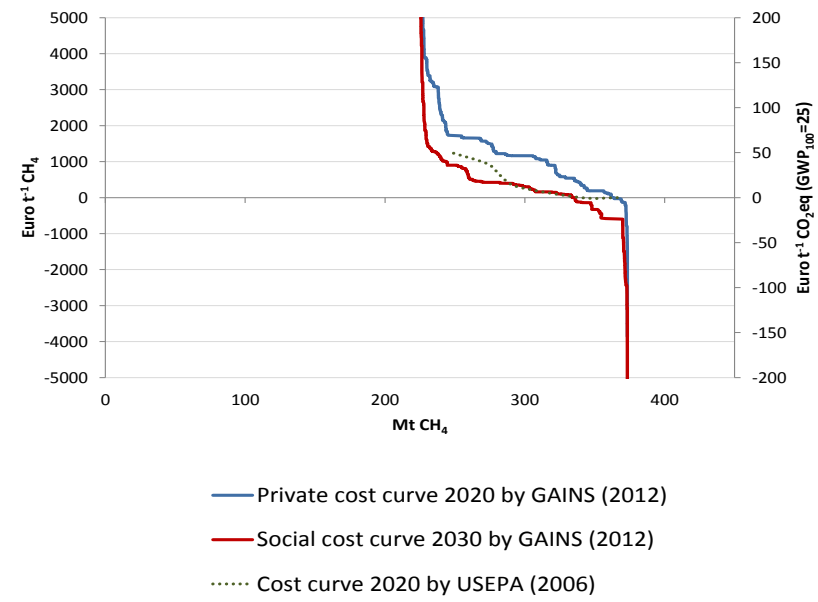

Fig. 6. Global $\mathrm{CH}_{4}$ mitigation cost curve 2020 with private and social cost perspectives and in comparison to USEPA (2006).

in 2030 when implemented to its full global potential. With a private cost perspective, the cost is, however, considerable at about 77 billion Euro per year. This is illustrated for the oil and gas sector in Fig. 8, where the red line depicting the marginal cost curve for oil production jumps from having almost half of the potential below zero cost with a social cost perspective to being well above the zero line with a private cost perspective. Hence, in particular for this sector the cost perspective matters and sole reliance on private investments is unlikely to initiate investments today in $\mathrm{CH}_{4}$ mitigation.

Another finding from Table 7 is that on a global scale, mitigation in waste and wastewater sectors are the least costly on average with a social cost perspective, however, the marginal cost differs considerably for treatment of different types of waste and industry. E.g. treating food waste residuals in anaerobic digestion with biogas recovery is estimated at a cost of about 2000 Euro t $^{-1} \mathrm{CH}_{4}$ for source separated household food waste, 261 Euro t $^{-1} \mathrm{CH}_{4}$ for solid waste from food industry and a net profit of 227 Euro $^{-1} \mathrm{CH}_{4}$ for wastewater from food industry. The differences in the cost take into account differences in collection and treatment costs as well as different potentials for converting the organic content into biogas (see Supplement for further details).

As shown in Fig. 8 a considerable technical mitigation potential at negative cost is found in the solid waste sector also with a private cost perspective. Apart from a limited potential to further extend recovery and utilization of black liquor from pulp and paper industry in developing countries, the profitable potential can be referred to recycling of household paper waste. The profitable potential estimated for this option should be interpreted with caution as the negative cost may be a result of distortions in the market for recycled pulp (see the Supplement for further discussion). The smaller mitigation potential in 2020 compared to 2030 reflects the delayed effect on emissions when decreasing landfill disposal of slow-degrading waste like paper and wood waste. The mitigation cost curve in 2020 only reflects mitigation of emissions from fast-degrading waste like food and garden waste.

Control of coal mining emissions is expected to account for 15 percent of the entire global technical mitigation potential in 2030 with more than a third in China. About 60 percent of the mitigation potential comes from controlling ventilation air methane (VAM) during mining of hard coal and 40 percent from pre-mining degasification. The weighted global marginal cost for degasification of hard coal mines is estimated at 957 Euro $\mathrm{t}^{-1} \mathrm{CH}_{4}$ with a social cost perspective and 1339 Euro t$^{-1} \mathrm{CH}_{4}$ with a private cost perspective. For China, the cost is estimated at 1223 Euro t $^{-1} \mathrm{CH}_{4}$ with a social cost perspective to be compared with 177 Euro t ${ }^{-1} \mathrm{CH}_{4}$ for US and Canada. The primary reason for this difference is the assumed higher costs for extending the infrastructure to utilize the recovered gas in China. The weighted global marginal cost for controlling ventilation air methane through oxidation is estimated at about 200 Euro t $^{-1} \mathrm{CH}_{4}$ in both cost perspectives. 
Table 8. Costs for $\mathrm{CH}_{4}$ technical mitigation potentials in 2030 by world region.

\begin{tabular}{|c|c|c|c|c|c|c|c|}
\hline \multirow[t]{2}{*}{ Cost range } & \multirow[t]{2}{*}{ World region } & \multicolumn{3}{|c|}{ Social cost perspective } & \multicolumn{3}{|c|}{ Private cost perspective } \\
\hline & & $\begin{array}{r}\text { Emission } \\
\text { reduction } \\
\mathrm{Mt} \mathrm{CH}_{4}\end{array}$ & $\begin{array}{r}\text { Marginal cost } \\
\text { (weighted average) } \\
\text { Euro } \mathrm{t}^{-1} \mathrm{CH}_{4}\end{array}$ & $\begin{array}{l}\text { Total cost } \\
10^{9} \text { Euro }\end{array}$ & $\begin{array}{r}\text { Emission } \\
\text { reduction } \\
\mathrm{Mt} \mathrm{CH}_{4}\end{array}$ & $\begin{array}{r}\text { Marginal cost } \\
\text { (weighted average) } \\
\text { Euro } \mathrm{t}^{-1} \mathrm{CH}_{4}\end{array}$ & $\begin{array}{c}\text { Total cost } \\
10^{9} \text { Euro }\end{array}$ \\
\hline \multirow{12}{*}{$\begin{array}{l}\text { Max technical } \\
\text { reduction } 2030\end{array}$} & Africa & 24.4 & -252 & -6.1 & 24.4 & 1067 & 26.1 \\
\hline & Asia - rest & 26.8 & -257 & -6.9 & 26.8 & 847 & 22.7 \\
\hline & Australia \& N Zealand & 1.7 & 395 & 0.7 & 1.7 & 1923 & 3.3 \\
\hline & China & 31.0 & -149 & -4.6 & 31.0 & 568 & 17.6 \\
\hline & EU-27 & 4.5 & -35 & -0.2 & 4.5 & 1925 & 8.7 \\
\hline & Europe - rest & 4.7 & -100 & -0.5 & 4.7 & 946 & 4.4 \\
\hline & India & 8.3 & -221 & -1.8 & 8.3 & 866 & 7.2 \\
\hline & Latin \& Central America & 25.7 & -287 & -7.4 & 25.7 & 696 & 17.9 \\
\hline & Middle east & 24.0 & -683 & -16.4 & 24.0 & 1140 & 27.4 \\
\hline & Russia & 31.2 & 104 & 3.3 & 31.2 & 907 & 28.3 \\
\hline & USA \& Canada & 12.3 & 829 & 10.2 & 12.3 & 2344 & 28.8 \\
\hline & World & 195 & -153 & -30 & 195 & 988 & 192 \\
\hline whereof $<1250$ & Africa & 23.2 & -408 & -9.5 & 9.2 & -217 & -5.0 \\
\hline \multirow{11}{*}{$\begin{array}{l}\text { Euro } \mathrm{t}^{-1} \mathrm{CH}_{4} \text { (i.e. } \\
<50 \text { Euro } \mathrm{t}^{-1} \\
\mathrm{CO}_{2} \text { eq.) }\end{array}$} & Asia - rest & 25.6 & -398 & -10.2 & 14.7 & -149 & -3.8 \\
\hline & Australia \& N Zealand & 1.5 & -109 & -0.2 & 1.0 & 253 & 0.4 \\
\hline & China & 30.5 & -183 & -5.6 & 25.2 & 133 & 4.0 \\
\hline & EU-27 & 3.9 & -602 & -2.3 & 2.6 & 210 & 0.8 \\
\hline & Europe - rest & 4.5 & -263 & -1.2 & 3.3 & 48 & 0.2 \\
\hline & India & 7.4 & -650 & -4.8 & 4.3 & -446 & -3.3 \\
\hline & Latin \& Central America & 24.7 & -414 & -10.2 & 22.0 & 241 & 5.9 \\
\hline & Middle east & 23.9 & -701 & -16.7 & 21.6 & 855 & 20.4 \\
\hline & Russia & 29.7 & 36 & 1.1 & 17.4 & 164 & 4.9 \\
\hline & USA \& Canada & 9.0 & -310 & -2.8 & 6.4 & 187 & 1.7 \\
\hline & World & 184 & -339 & -62 & 128 & 205 & 26 \\
\hline whereof $<500$ & Africa & 20.1 & -612 & -12.3 & 3.7 & -563 & -11.3 \\
\hline \multirow{11}{*}{$\begin{array}{l}\text { Euro } \mathrm{t}^{-1} \mathrm{CH}_{4} \text { (i.e. } \\
<20 \text { Euro t }^{-1} \\
\mathrm{CO}_{2} \text { eq.) }\end{array}$} & Asia - rest & 20.5 & -696 & -14.3 & 9.3 & -453 & -9.3 \\
\hline & Australia \& N Zealand & 1.3 & -263 & -0.4 & 0.9 & 173 & 0.2 \\
\hline & China & 19.0 & -817 & -15.5 & 15.2 & -374 & -7.1 \\
\hline & EU-27 & 3.1 & -1033 & -3.2 & 1.4 & -135 & -0.4 \\
\hline & Europe - rest & 3.5 & -599 & -2.1 & 1.8 & -336 & -1.2 \\
\hline & India & 5.9 & -1034 & -6.1 & 3.9 & -631 & -3.7 \\
\hline & Latin \& Central America & 21.6 & -593 & -12.8 & 5.3 & -280 & -6.1 \\
\hline & Middle east & 22.1 & -830 & -18.4 & 1.6 & -116 & -2.6 \\
\hline & Russia & 26.4 & -56 & -1.5 & 9.9 & -73 & -1.9 \\
\hline & USA \& Canada & 8.0 & -496 & -4.0 & 5.2 & 37 & 0.3 \\
\hline & World & 152 & -597 & -90 & 58 & -740 & -43 \\
\hline \multirow{12}{*}{$\begin{array}{l}\text { whereof }<250 \\
\text { Euro t }{ }^{-1} \mathrm{CH}_{4} \text { (i.e. } \\
<10 \text { Euro t }{ }^{-1} \\
\mathrm{CO}_{2} \text { eq.) }\end{array}$} & Africa & 8.0 & -2020 & -16.2 & 3.6 & -1410 & -11.3 \\
\hline & Asia - rest & 11.4 & -1513 & -17.3 & 7.3 & -874 & -10.0 \\
\hline & Australia \& N Zealand & 1.3 & -300 & -0.4 & 0.0 & -29 & 0.0 \\
\hline & China & 16.0 & -1024 & -16.4 & 13.9 & -474 & -7.6 \\
\hline & EU-27 & 2.7 & -1204 & -3.3 & 1.1 & -192 & -0.5 \\
\hline & Europe - rest & 3.2 & -690 & -2.2 & 1.6 & -387 & -1.2 \\
\hline & India & 2.0 & -3799 & -7.5 & 1.3 & -2339 & -4.6 \\
\hline & Latin \& Central America & 19.0 & -733 & -13.9 & 3.4 & -363 & -6.9 \\
\hline & Middle east & 21.8 & -850 & -18.5 & 1.6 & -118 & -2.6 \\
\hline & Russia & 14.8 & -379 & -5.6 & 9.1 & -151 & -2.2 \\
\hline & USA \& Canada & 7.0 & -602 & -4.2 & 3.7 & -13 & -0.1 \\
\hline & World & 107 & -984 & -106 & 47 & -1008 & -47 \\
\hline \multirow{12}{*}{$\begin{array}{l}\text { whereof } \\
<0 \text { Eurot }{ }^{-1} \mathrm{CH}_{4}\end{array}$} & Africa & 3.7 & -4494 & -16.6 & 3.1 & -3079 & -11.4 \\
\hline & Asia - rest & 6.4 & -2773 & -17.9 & 5.0 & -1614 & -10.4 \\
\hline & Australia \& N Zealand & 0.5 & -1135 & -0.5 & 0.0 & -79 & 0.0 \\
\hline & China & 5.0 & -3629 & -18.2 & 2.9 & -1931 & -9.7 \\
\hline & EU-27 & 1.6 & -2200 & -3.4 & 0.7 & -389 & -0.6 \\
\hline & Europe - rest & 1.6 & -1486 & -2.4 & 0.6 & -847 & -1.4 \\
\hline & India & 1.8 & -4110 & -7.5 & 1.3 & -2523 & -4.6 \\
\hline & Latin \& Central America & 14.3 & -1026 & -14.7 & 3.0 & -488 & -7.0 \\
\hline & Middle east & 20.1 & -938 & -18.9 & 1.6 & -128 & -2.6 \\
\hline & Russia & 8.5 & -716 & -6.1 & 7.7 & -284 & -2.4 \\
\hline & USA \& Canada & 5.6 & -820 & -4.6 & 0.5 & -64 & -0.4 \\
\hline & World & 69 & -1602 & -111 & 26 & -1911 & -50 \\
\hline
\end{tabular}


Table 9. Comparison of GAINS model results for baseline global anthropogenic $\mathrm{CH}_{4}$ emissions with the results of other models.

\begin{tabular}{|c|c|c|c|c|c|c|c|c|c|c|c|}
\hline \multirow[t]{4}{*}{ Year } & \multirow[t]{4}{*}{ Major sector } & \multicolumn{10}{|c|}{ Model/Database } \\
\hline & & GAINS & GAINS & GAINS & USEPA & USEPA & EDGAR & MiniCAM & IMAGE & MESSAGE & AIM \\
\hline & & $\begin{array}{r}\text { This } \\
\text { study }\end{array}$ & $\begin{array}{l}\text { UNEP } \\
(2011)\end{array}$ & $\begin{array}{r}\text { Cofala et } \\
\text { al. (2007) }\end{array}$ & $\begin{array}{r}\text { Draft } \\
\text { Aug } 2011\end{array}$ & 2006 & $\mathrm{v} 4.2$ & RCP 4.5 & RCP3 PD (2.6) & RCP 8.5 & RCP 6.0 \\
\hline & & \multicolumn{10}{|c|}{$\mathrm{Mt} \mathrm{CH}_{4}$} \\
\hline \multirow[t]{6}{*}{ Baseline 2005} & Agriculture & 123 & 123 & 130 & 133 & $170^{\mathrm{a}}$ & 143 & 126 & 133 & 134 & 136 \\
\hline & Waste \& wastewater & 57 & 50 & 69 & 57 & 62 & 58 & 63 & 55 & 73 & 62 \\
\hline & Fuel produc., transport. \& energy use & 140 & 112 & 96 & 114 & 74 & 122 & 85 & 92 & 104 & 87 \\
\hline & Burning of agr. waste, grassland, forest & 3 & 3 & 11 & 20 & 0 & 24 & 27 & 27 & 26 & 27 \\
\hline & Industrial processes & 0 & 0 & 0 & 0 & 0 & 0 & 2 & 2 & 1 & 1 \\
\hline & Total & 323 & 288 & 305 & 325 & 306 & 346 & 302 & 309 & 339 & 314 \\
\hline \multirow[t]{6}{*}{ Baseline 2030} & Agriculture & 143 & 143 & 149 & 157 & $175^{\mathrm{b}}$ & n.a. & 152 & 126 & 186 & 151 \\
\hline & Waste \& wastewater & 78 & 58 & 83 & 69 & $71^{b}$ & n.a. & 67 & 28 & 127 & 56 \\
\hline & Fuel produc., transport. \& energy use & 189 & 160 & 190 & 159 & $108^{b}$ & n.a. & 95 & 50 & 159 & 88 \\
\hline & Burning of agr. waste, grassland, forest & 4 & 4 & 8 & 20 & 0 & n.a. & 16 & 26 & 25 & 28 \\
\hline & Industrial processes & 0 & 0 & 0 & 0 & 0 & n.a. & 2 & 3 & 3 & 2 \\
\hline & Total & 414 & 365 & 430 & 405 & $354^{\mathrm{b}}$ & n.a. & 332 & 233 & 499 & 325 \\
\hline
\end{tabular}

a 2005 value derived from linear interpolation between 2000 and 2020 values, ${ }^{\text {b }}$ Baseline 2020 (estimates for 2030 not available).

Sources: UNEP (2011); Cofala et al. (2007); USEPA (2006;2011); EDGAR (2012); IIASA (2012).
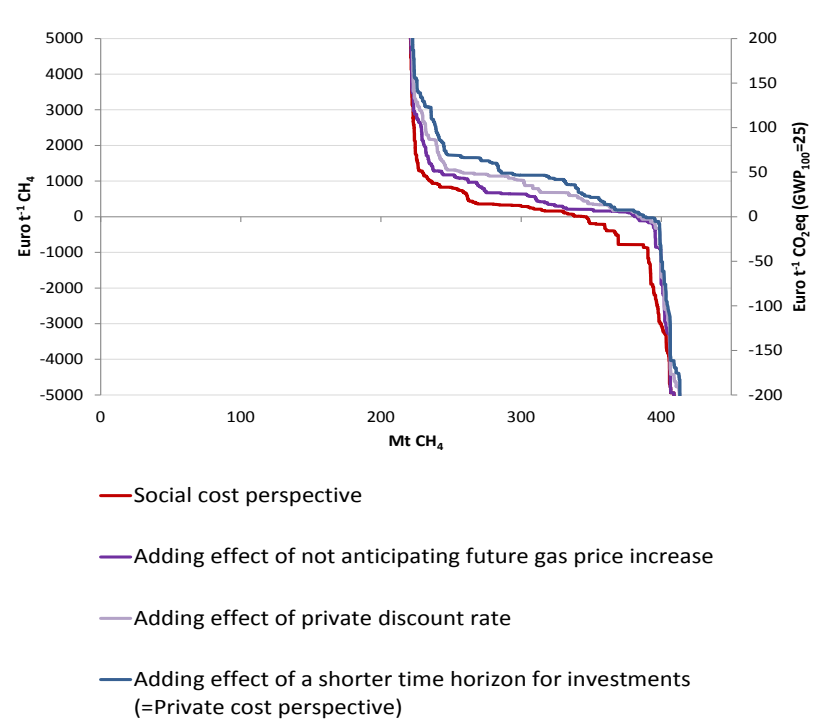

Fig. 7. Global $\mathrm{CH}_{4}$ mitigation cost curve 2030 with private and social cost perspectives including a separation of the effects of the differences in assumptions between the social and private cost perspectives.

Rice cultivation mitigation options do not involve capital investments nor recovery of gas. The marginal cost curves for the social and private cost perspectives therefore coincide in Fig. 8.

Region-specific $\mathrm{CH}_{4}$ mitigation costs in 2030 for different cost ranges are presented in Table 8. Estimation results show that with a social cost perspective almost 80 percent of the technical mitigation potential is available at a marginal cost less than 500 Euro t $^{-1} \mathrm{CH}_{4}$ (i.e. 20 Euro t $^{-1} \mathrm{CO}_{2}$ eq.). With a private cost perspective, this fraction is only 30 percent. The fraction of the entire technical mitigation potential available at a net profit is estimated at 35 percent with a social cost perspective and 13 percent with a private cost perspective. As expected, major fossil fuel producing regions like Russia, China, Latin \& Central America, Africa and the Middle East have considerable technical mitigation potentials at low social costs but often at substantial private costs. There are only limited technical mitigation potentials available at low costs in India, Europe, Australia and New Zealand. The large mitigation potential at low cost foreseen in countries that are currently not among Annex 1 countries under the Kyoto protocol, shows the importance of finding future political solutions for methane which address emissions also in these regions.

\subsection{Comparison to other global inventories}

Table 9 presents global $\mathrm{CH}_{4}$ emissions as estimated in the current version of the GAINS model and in comparison with previous estimates using the GAINS model as well as estimates using other models and databases. These include estimates by USEPA with projections until 2030 (draft version from August 2011) and projections until 2020 (final version from 2006), an inventory of historical emissions by the EDGAR online database (2012) version 4.2, as well as comparisons to IPCC's Representative Concentration Pathways (RCPs) (Moss et al., 2008). The RCPs provide pathways until 2100 for emissions of all greenhouse gases including $\mathrm{CH}_{4}$ and represent four different future pathways, where RCP 3$\mathrm{PD}$ assumes a peak and decline in greenhouse gases, the RCP 4.5 and RCP 6.0 stabilizations at radiative forcing of 4.5 or $6.0 \mathrm{~W} \mathrm{~m}^{-2}$ and $\mathrm{RCP} 8.5$ assumes rising radiative forcing to $8.5 \mathrm{~W} \mathrm{~m}^{-2}$ in 2100 (IIASA, 2012).

A comparison of baseline 2005 emission estimates suggests a close agreement across models at an aggregate level, but with differences at a sector level. The GAINS estimates presented in this study produce generally higher estimates for 

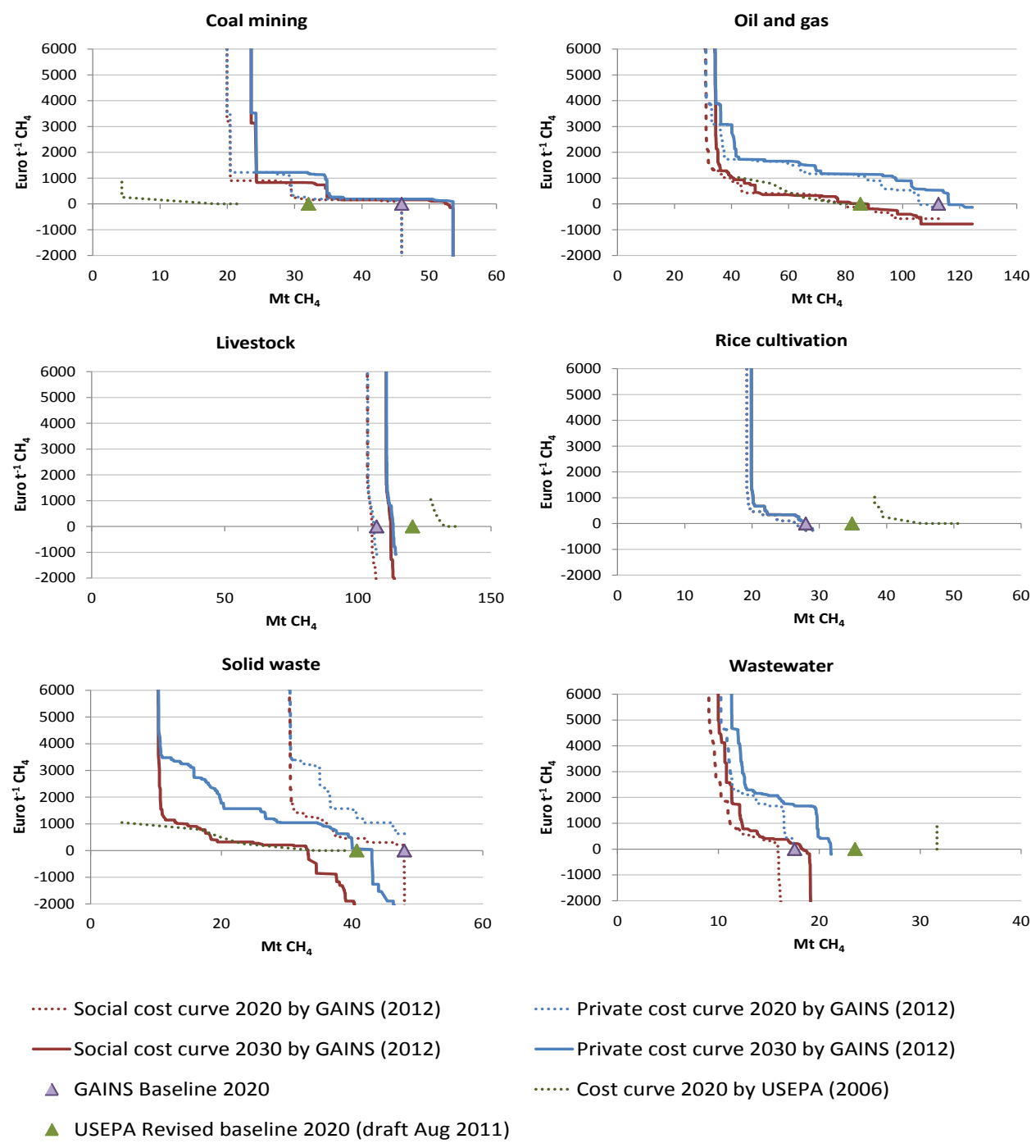

..... Cost curve 2020 by USEPA (2006)

Fig. 8. Global $\mathrm{CH}_{4}$ mitigation cost curve 2020 and 2030 by sector with private and social cost perspectives and in comparison to USEPA (2006).

emissions from fossil fuel production. The higher estimates are likely to derive from the extensive use of country-specific information in the estimations of emissions as well as the separation of emission estimates for venting of associated gas and unintended leakage from oil and gas production. The use of recent measurement results on the amounts of associated gas vented as opposed to flared during extraction of different types of hydrocarbons (Johnson and Coderre, 2011) and verification against country-specific satellite images of flares (NOAA, 2010) have also contributed to higher emissions in recent GAINS estimates. The coverage of $\mathrm{CH}_{4}$ emissions from open burning of agricultural waste, pre-scribed burning of grasslands and human-induced forest fires appears less complete in GAINS than in other models. GAINS only includes emissions from open burning of agricultural waste using data from Niemi (2006), whereas emissions from grass- land burning and forest fires have not been included due to lack of systematic data. In models where these sources are included they account for about $20 \mathrm{Mt} \mathrm{CH}_{4}$ per year or about seven percent of global $\mathrm{CH}_{4}$ emissions.

Figure 9 shows projections of global $\mathrm{CH}_{4}$ emissions in the different models and scenarios. The current GAINS projection for global baseline $\mathrm{CH}_{4}$ emissions until 2030 is almost identical to the draft USEPA (2011) projection. This is likely a result of both projections using the IEA World Energy Outlook (2009) reference scenario as driver for macroeconomic and energy activity data. As seen in Fig. 9, without further measures to reduce $\mathrm{CH}_{4}$ emissions, the GAINS and USEPA baseline estimates suggest a future emission path which clearly exceeds the two IPCC stabilization pathways RCP 4.5 and RCP 6.0. On the other hand, with full implementation of currently available mitigation technology, the 


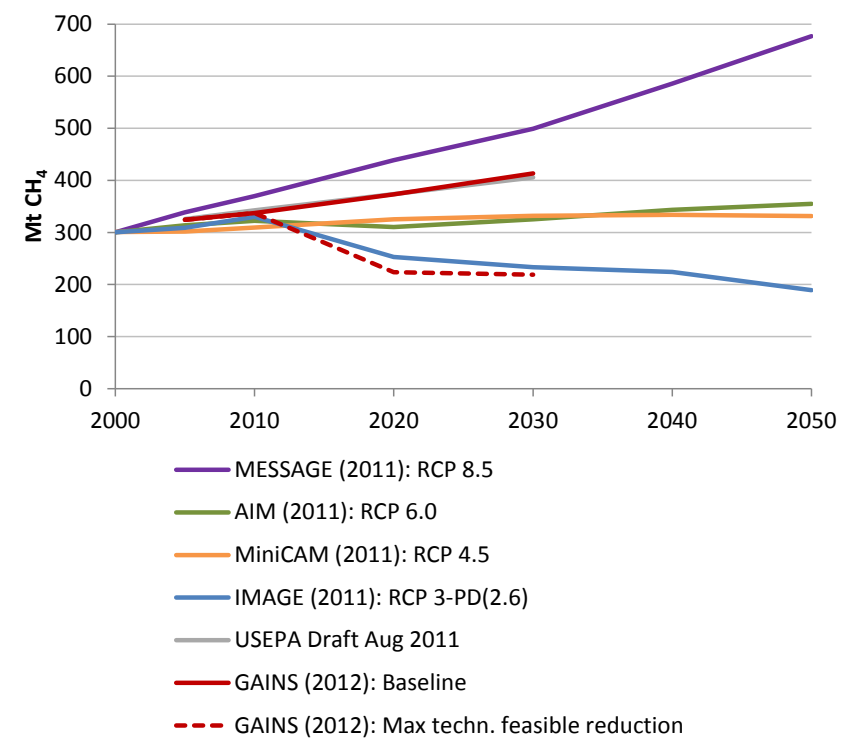

Fig. 9. Projection of baseline global anthropogenic $\mathrm{CH}_{4}$ emissions in GAINS and in comparison to other models.

GAINS model results show that it is technically possible until 2030 to enter a future emission path that is consistent with the IPCC peak and decline scenario RCP 3-PD.

USEPA (2006) estimated global anthropogenic $\mathrm{CH}_{4}$ mitigation cost curves for year 2020. The marginal mitigation cost curves included mitigation measures in the range up to $60 \$ \mathrm{t} \mathrm{CO}_{2}$ eq. The financial assumptions were a discount rate of 10 percent and a tax rate of 40 percent. In Fig. 6, the USEPA global $\mathrm{CH}_{4}$ mitigation cost curve for 2020 has been entered for comparison. As shown, it follows quite closely the social perspective cost curve in GAINS despite the differences in financial assumptions. A sector break down of the cost curves presented in Fig. 8 reveals some differences. Baseline emissions from coal mining and oil and gas production are higher in GAINS than in the USEPA estimates and therefore the mitigation potentials are larger, however, USEPA marginal cost levels are still close to those in GAINS. The mitigation potential for livestock is larger in the USEPA estimate, because additional measures to control enteric fermentation emissions are included, e.g. use of antibiotics or bovine somatotropin, propionate precursors and antimethanogen vaccine. Wide-spread adoption of propionate precursors and vaccines are in GAINS only considered available after 2030 (Höglund-Isaksson et al., 2012). The use of antibiotics or bovine somatotropin as $\mathrm{CH}_{4}$ control options, are in GAINS considered infeasible due to the adverse effects on human and animal health. The USEPA mitigation cost curve for the solid waste sector in 2020 corresponds well to the social perspective cost curve for 2030 in GAINS. In GAINS, the 2020 mitigation potential is smaller and more costly as it only refers to the mitigation potential of fast-degrading waste like food and garden waste. For slow-

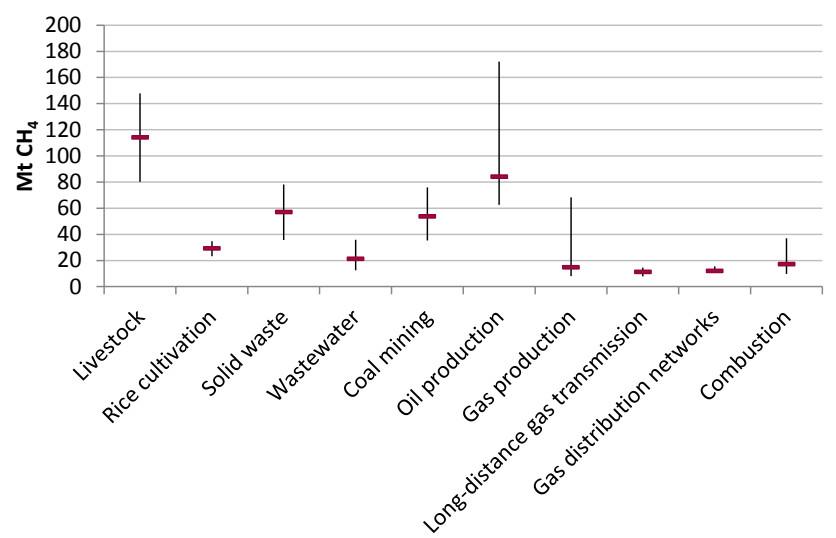

Fig. 10. Uncertainty ranges by sector for global $\mathrm{CH}_{4}$ emission estimates in Baseline 2030.

degrading waste like paper and wood, the long time lag between disposal and emissions makes the effects on emissions only become visible in the 2030 cost curve. For the wastewater sector, USEPA does not consider any mitigation potential, while it is quite substantial, although relatively costly, in GAINS.

\section{Uncertainty}

There are several different types of uncertainty that enter into model estimations of emissions. EC4MACS (2010) distinguishes five different types: uncertainty in data, in model structure and methodology, in expert judgements, in the chosen system boundaries and in the choice of output indicators. This section focuses on uncertainty in the chosen methodology and information input used in the derivation of emission factors as well as uncertainty due to system boundaries. It does not address uncertainty in the projections of activity drivers as these have been taken from external sources.

Identifying reasons for and assessing approximate magnitudes of uncertainty in emission estimations is useful to find out the relative importance of estimation errors in individual assumptions on a global scale. By identifying particularly critical assumptions, the analysis can provide insights into what areas need further research to best reduce uncertainty in global $\mathrm{CH}_{4}$ emission estimates. Uncertainty ranges have been quantified using default ranges suggested in the IPCC (2006) guidelines or when emission factors were derived from country-specific information, e.g. for the oil and gas production sectors, default uncertainty ranges were adjusted to take account of the better precision provided by the country-specific information. A detailed description of the uncertainty sources identified for each sector is presented in the Supplement.

Figure 10 presents the ranges for the identified sources of uncertainty in each sector. Merging up the sector uncertainty ranges to a global scale is not considered possible as it would 

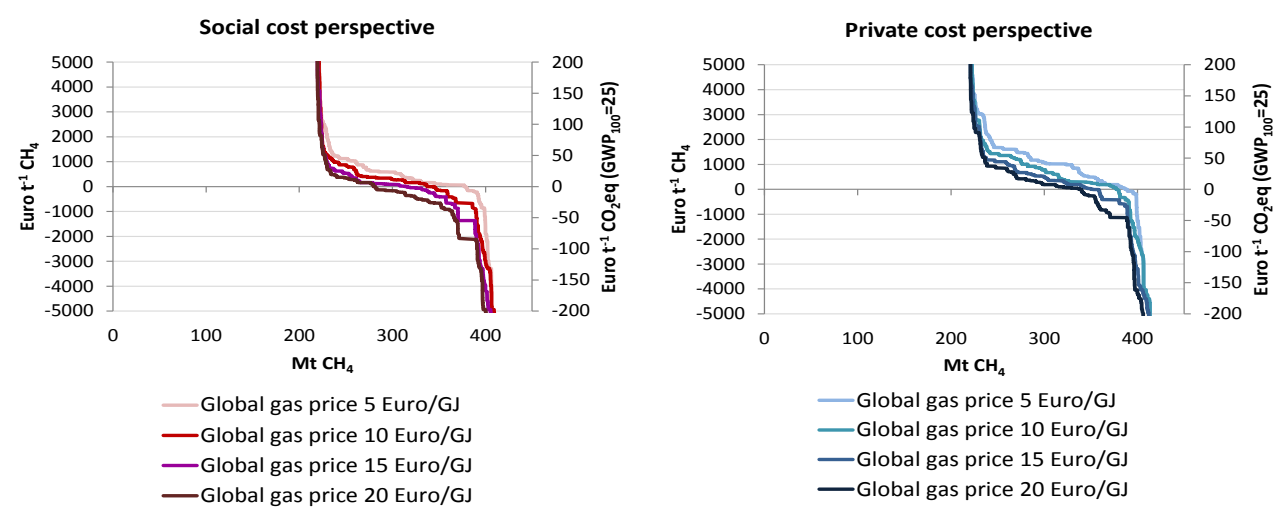

Fig. 11. Sensitivity of the global marginal mitigation cost curve in 2030 to different assumptions about the future gas price level.

require knowledge about the probability distributions of the sector ranges. With such knowledge, a global uncertainty range could have been obtained using Monte-Carlo simulation (Winiwarter and Rypdal, 2001). Despite this shortcoming, a comparison across sectors can still be useful as it allows for identifying which emission sources contribute the most to uncertainty in emission estimates. Based on the uncertainty sources identified here, global baseline emission estimates suffer the most from uncertainty in estimates of oil and gas production emissions. To reduce uncertainty it would be particularly desirable to obtain more measurement data on the fraction of associated gas vented as opposed to flared from extraction of different types of hydrocarbons in various parts of the world. It would also be an advantage to improve access to measurement data which could verify reported data, e.g. amounts of associated gas generated for major oil and gas producing countries (see example with Saudi Arabia in the Supplement). Livestock, solid waste and wastewater are sources with generally high uncertainty in emission estimates due to many small point sources and large site-specific variation in emission factors due to e.g. climatic factors and management practices. Reducing uncertainty in emission estimates for these sectors would include improved access to country- or provincial information, which would allow for further disaggregating the model structure to better take account of the variation in local conditions.

Just like for the estimation of baseline emissions, uncertainty is also present in the estimations of mitigation potentials. The cause for the uncertainty is similar in that lack of detailed country-specific information makes it necessary to use default assumptions. In contrast to baseline emissions, the IPCC guidelines do not provide uncertainty ranges for the estimation of mitigation potentials for different types of mitigation technology. This makes it difficult to quantify such uncertainty ranges here.

This paper has made an effort to improve the general understanding of the complexity by which different factors influence mitigation costs for $\mathrm{CH}_{4}$, which is intended to reduce uncertainty in mitigation cost estimates. Still, it is inevitable that lack of information is sometimes bridged by the use of default assumptions. Again, lack of default assumptions for uncertainty ranges makes it difficult to quantify such ranges here. Uncertainty in drivers for future mitigation costs can still be analyzed, e.g. how different future gas price levels influence costs. Figure 11 illustrates the global $\mathrm{CH}_{4}$ marginal mitigation cost curve in 2030 for a range of future global gas price levels from 5 to 20 Euro $\mathrm{GJ}^{-1}$. At lower gas price levels, the cost of controlling leakage of natural gas or recovering biogas increases, which shifts the marginal mitigation cost curve up. It is noteworthy that even if private investors anticipated a future gas price of 20 Euro GJ ${ }^{-1}$ in their investment decisions, only 38 percent of the entire mitigation potential in 2030 is found available at a net profit.

\section{Conclusions}

This analysis identifies and quantifies major global sources of anthropogenic methane $\left(\mathrm{CH}_{4}\right)$ emissions as well as technical opportunities and costs for mitigation. It also pinpoints important sources of uncertainty in emission estimations, which could serve to improve future estimates.

Without further mitigation efforts than currently in place or prescribed by adopted legislation, global anthropogenic $\mathrm{CH}_{4}$ emissions are expected to grow from $323 \mathrm{Mt} \mathrm{CH}_{4}$ in 2005 to $414 \mathrm{Mt}$ in 2030 , i.e. a growth by 28 percent. The full technical mitigation potential could almost halve baseline emissions in 2030. The fraction of the global technical mitigation potential available at a net profit is estimated at 35 percent with a social cost perspective and 13 percent with a private cost perspective. With a social cost perspective, almost 80 percent of the technical mitigation potential is found available at a marginal cost below 500 Euro ${ }^{-1} \mathrm{CH}_{4}$ (i.e. 20 Euro $^{-1} \mathrm{CO}_{2}$ eq.), while the corresponding fraction with a private cost perspective is 30 percent. More than 60 percent of the entire technical mitigation potential is found in sectors involving fossil fuel production and use. From a 
social cost perspective most of these options come at a net profit, while for a private investor costs are usually considerable. Mitigation opportunities in agriculture are found limited and often costly both from social and private cost perspectives. About 30 percent of the global technical mitigation potential is found in waste and wastewater sectors. Options in these sectors are often sensitive to uncertainty in the future gas price level because they often involve recovery of biogas from treatment of biodegradable waste or wastewater.

$\mathrm{CH}_{4}$ is a forceful but relatively short-lived greenhouse gas, which means that mitigation of $\mathrm{CH}_{4}$ emissions can achieve considerable alleviations in global warming already in the short run. This study has shown there exists considerable technical potential to reduce global anthropogenic $\mathrm{CH}_{4}$ emissions. Although costs are expected to fall in the future following an expected increase in the gas price, the costs facing private investors today are not likely attractive enough to initiate mitigation. Hence, for fast action to reduce global $\mathrm{CH}_{4}$ emissions, public intervention through regulations or incentivebased schemes are needed. Such efforts should also address countries currently not regulated under the Kyoto protocol, as most of the low-cost mitigation potential is found in these regions.

\section{Supplementary material related to this article is available online at: http://www.atmos-chem-phys.net/12/ 9079/2012/acp-12-9079-2012-supplement.pdf.}

Acknowledgements. The author wants to thank two anonymous reviewers as well as colleagues at IIASA for valuable comments and suggestions. She is also grateful for insightful discussions with Richard Mattus on $\mathrm{CH}_{4}$ mitigation from coal mining and Paal Jahre Nilsen and Hans Rasmus Holte on biogas generation.

Edited by: F. Dentener

\section{References}

Amann, M., Bertok, I., Borken-Kleefeld, J., Cofala, J., Heyes, C., Höglund-Isaksson, L., Klimont, Z., Nguyen, B., Posch, M., Rafaj, P., Sandler, R., Schöpp, W., Wagner, F., and Winiwarter, W.: Cost-effective control of air quality and greenhouse gases in Europe: Modelling and policy applications, Environ. Model. Softw., 26, 1489-1501, 2011.

Brunner, S., Flachsland, C., and Marschinski, R.: Credible commitment in carbon policy, Climate Policy, 12, 255-271, 2012.

CAPRI model: Common Agricultural Policy Regional Impact Analysis Model, Bonn University, Bonn, 2009.

China University of Petroleum: Feasibility study of coal bed methane production in China, EU-China Energy and Environment Programme, EuropeAid/120723/D/SV/CN, Beijing, March 2008.
CIA World Factbook: US Central Intelligence Agency, Washinton DC, 2010.

Cofala, J., Amann, M., Klimont, Z., Kupianien, K., and HöglundIsaksson, L.: Scenarios of global anthropogenic emissions of air pollutants and methane until 2030, Atmos. Environ., 41, 84868499, 2007.

Eawag: Global waste challenge, Swiss Federal Institute for Aquatic and Science and Technology, Dübendorf, Switzerland, 2008.

EC: Sugar - international analysis, production structures within the EU, European Commission, Brussels, 2003.

EC4MACS: TF1AM/EC4MACS workshop on uncertainty treatment, Report by the chair, European Consortium for Modeling of Air Pollution and Climate Strategies, International Institute for Applied Systems Analysis, Laxenburg, November, 2010.

Ecofys: Methane and nitrous oxide, Sectoral emission reduction potentials and economic costs for climate change policies SERPEC-CC, Report for DG Environment, European Commission, Ecofys, Utrecht, 2009.

EDGAR database: Emission database for global atmospheric research, version 4.2, Netherlands Environmental Assessment Agency and Joint Research Centre of the European Commission, 2012.

EUROSTAT: http://epp.eurostat.ec.europa.eu/, Data on waste amounts downloaded on 18 September 2006, European Commission, Brussels, 2005.

EUROSTAT: http://epp.eurostat.ec.europa.eu/, Data on livestock numbers downloaded 25 June 2009, European Commission, Brussels, 2009.

FAO: World agriculture: towards 2015/2030 - Summary report, Food and Agriculture Organization of the United Nations, Rome, 2003.

FAO: Wastewater database, Food and Agriculture Organization, Rome, 2009.

FAOSTAT: http://faostat.fao.org, Data on rice cultivation area and livestock numbers downloaded in June 2010, Food and Agriculture Organization, Rome, 2010.

FAOSTAT: http://faostat.fao.org,, Data on relevant food industry production quantities downloaded in August 2011, Food and Agriculture Organization, Rome, 2011.

Höglund-Isaksson, L. and Mechler, R.: The GAINS Model for Greenhouse Gases - Version 1.0: Methane $\left(\mathrm{CH}_{4}\right)$, IIASA Interim Report IR-05-054, International Institute for Applied Systems Analysis, Laxenburg, 2005.

Höglund-Isaksson, L., Winiwarter, W., and Tohka, A.: Potentials and costs for mitigation of non- $\mathrm{CO}_{2}$ greenhouse gases in Annex 1 countries, Version 2, International Institute for Applied Systems Analysis, Laxenburg, available at: http://gains.iiasa.ac. at/gains/reports/AnnexI-nonCO2.pdf, July 2009.

Höglund-Isaksson, L., Winiwarter, W., Purohit, P., Rafaj, P., Schöpp, W., and Klimont, Z.: EU low carbon roadmap 2050: Potentials and costs for mitigation of non- $\mathrm{CO}_{2}$ greenhouse gas emissions, Energy Strategy Reviews, 1, 97-108, 2012.

IIASA: RCP database version 2.0, http://www.iiasa.ac.at/web-apps/ tnt/RcpDb/, International Institute for Applied Systems Analysis, Laxenburg, 2 July, 2012.

IEA: Natural Gas Information 2009, IEA Statistics, International Energy Agency, Paris, 2010.

IEA-WEO: IEA World Energy Outlook 2009, International Energy Agency, Paris, 2009. 
ILO: LABORSTA statistical database, International Labour Office, Geneva, 2010.

IPCC: Revised 1996 IPCC Guidelines for National Greenhouse Gas Inventories, Intergovernmental Panel on Climate Change, UK, 1997.

IPCC: 2006 IPCC Guidelines for National Greenhouse Gas Inventories, Intergovernmental Panel on Climate Change, Japan, 2006.

IPCC: IPCC Fourth Assessment Report, Intergovernmental Panel on Climate Change, Geneva, 2007.

Johnson, M. R. and Coderre, A. R.: An analysis of flaring and venting activity in the Alberta upstream oil and gas industry, J. Air Waste Manage., 61, 190-200, 2011.

Moss, R., Babiker, M., Brinkman, S., Calvo, E., Carter, T., Edmonds, J., Elgizouli, I., Emori, S., Erda, L., Hibbard, K., Jones, R., Kainuma, M., Kelleher, J., Lamarque, J. F., Manning, M., Matthews, B., Meehl, J., Meyer, L., Mitchell, J., Nakicenovic, N., O'Neill, B., Pichs, R., Riahi, K., Rose, S., Runci, P., Stouffer, R., van Vuuren, D., Weyant, J., Wilbanks, T., van Ypersele, J. P., and Zurek, M.: Towards New Scenarios for Analysis of Emissions, Climate Change, Impacts, and Response Strategies. Intergovernmental Panel on Climate Change (IPCC), Geneva, 2008.

Newbold, C. J., Lopez, S., Nelson, N., Ouda, J. O., Wallace, R. J., and Moss, A. R.: Propionate precursors and other metabolic intermediates as possible alternative electron acceptors to methanogenesis in ruminal fermentation, British Journal of Nutrition, 94, 27-35, 2005.

Niemi, J. V.: Atmospheric emissions from open biomass burning - development of datasets for RAINS model, IIASA Interim Report IR-05-007, International Institute for Applied Systems Analysis (IIASA), Laxenburg, 2006.

NOAA: Global Gas Flaring Estimates Database, National Geophysical Data Centre, Boulder, 2010.

OECD/IEA: Projected costs of generating electricity, OECD Nuclear Energy Agency and International Energy Agency, Paris, 2005.

Persson, M.: Utvärdering av uppgraderingstekniker för biogas, Evaluation of upgrading techniques for biogas, SGC Rapport 142, Swedish Centre for Gas Technology, Malmö, 2003 (in Swedish).

Shindell, D., Kuylenstierna, J. C. I., Vignati, E., van Dingenen, R., Amann, M., Klimont, Z., Anenberg, S. C., Muller, N., JanssensMaenhout, G., Raes, F., Schwartz, J., Faluvegi, G., Pozzoli, L., Kupiainen, K., Höglund-Isaksson, L., Emberson, L., Streets, D., Ramanathan, V., Hicks, K., Oanh, N. T. K., Milly, G., Williams, M., Demkine, V., and Fowler, D.: Simultaneously mitigating near-term climate change and improving human health and food security, Science, 335, 183-189, 2012.
UN: Population database, United Nations Department of Economic and Social Affairs, New York, 2009.

UN: Environmental indicators database - water, United Nations Department of Economic and Social Affairs, New York, 2010.

UNEP: Near-term climate protection and clean air benefits: actions for controlling short-lived climate forcers, A UNEP synthesis report, United Nations Environment Programme, Nairobi, November 2011.

UNFCCC: Common Reporting Format (CRF) tables and National Inventory Reports (NIRs) (version downloaded in April 2010), United Nations Framework Convention on Climate Change, Bonn, 2010.

USDA: Sugar: world markets and trade, database, United States Department of Agriculture, Washington DC, 2011.

USEPA: Assessment of the worldwide market potential for oxidizing coal mine ventilation air methane, EPA 430-R-03-002, US Environmental Protection Agency, 2003.

USEPA: Global mitigation of non-CO2 Greenhouse Gases, EPA 430-R-06-005, United States Environmental Protection Agency, Washington DC, June 2006.

USEPA: DRAFT: Global anthropogenic non-CO2 greenhouse gas emissions: 1990-2030, EPA 430-D-11-003, US Environmental Protection Agency, Washington DC, August 2011.

Winiwarter, W. and Rypdal, K.: Assessing the uncertainty associated with national greenhouse gas emission inventories: a case study for Austria, Atmos. Enviro., 35, 5425-5440, 2001.

Wright, A. D. G., Kennedy, P., O’Neill, C. J., Toovey, A. F., Popovski, S., Rea, S. M., Pimm, C. L., and Klein, L.: Reducing methane emissions in sheep by immunization against rumen methanogens, Vaccine, 22, 3976-3985, 2004.

Wuppertal Institute: Greenhouse gas emissions from Russian natural gas export pipeline system, Final Report, Wuppertal Institute for Climate, Environment and Energy in cooperation with MaxPlanck-Institute for Chemistry, Wuppertal and Mainz, 2005. 